Board of Governors of the Federal Reserve System

International Finance Discussion Papers

Number 501

February 1995

\title{
REAL EXCHANGE RATE MOVEMENTS IN HIGH INFLATION COUNTRIES
}

John H. Rogers and Ping Wang

Note: International Finance Discussion Papers are preliminary materials circulated to stimulate discussion and critical comment. Reference in publications to International Finance Discussion Papers (other than acknowledgement that the writer has had access to unpublished material) should be cleared with the author or authors. 


\begin{abstract}
We: empirically assess the sources of fluctuations in the real exchange rates of four high inflation countries, for which monetary shocks are generally believed to be predominant. In a benchmark model we identify fiscal, monetary, and output shocks based on a general-equilibrium optimizing model. We then estimate two alternative extensions. In the first, we decompose the output shock into supply and demand disturbances; in the second, the monetary shock is further decomposed into money supply and nominal exchange rate disturbances. Monetary shocks are found to be generally significant. Real shocks, especially those associated with government policy restrictions on the flow of currency, income from foreign investments, capital, and/or goods, are uniformly more influential however. The paper suggests that analyses of real exchange rates in high inflation economies using models emphasizing monetary shocks and sticky prices could be improved by not neglecting real shocks.
\end{abstract}




\section{Real Exchange Rate Movements in High Inflation Countries}

John H. Rogers and Ping Wang ${ }^{1}$

\section{INTRODUCTION}

The real exchange rate represents the relative price of a basket of consumption goods in one country to that of another. Over the last two decades, real exchange rate volatility has been a prominent feature of the international monetary system. ${ }^{2}$

Cine strand of the literature seeks to explain the factors underlying real exchange rate movements by linking statistical evidence on real exchange rates, nominal exchange rates, prices, and other masroeconomic variables with theoretical models of the exchange rate. These studies include Campbell and Clarida (1987), Meese and Rogoff (1988), Mark (1990), Baxter (1993, 1994), Edison and Pauls (1993), Engel (1993), and Engel and Rogers (1994). ${ }^{3}$

${ }^{1}$ The first author is a staff economist in the Division of International Finance of the Board of Governors of the Federal Reserve System. The second author is an associate professor of Economics at Penn State University. The views expressed in this paper are solely the responsibility of the authors and should not be interpreted as reflecting those of the Board of Governors of the Federal Reserve Siystem or other members of its staff. We have greatly benefited from suggestions by Shaghil Ahmed, Nathan Balke, Eric Bond, Roberto Chang, Larry Christiano, Barry Ickes, Finn Kydland, Eric Leeper, David Papell, Ellis Tallman, seminar participants at the Atlanta Fed, Dallas Fed, Houston, Indiana, and Penn State. Special thanks go to Sam Yoo, whose ideas gave birth to this project. Kelly MacFarland provided excellent research assistance. Part of this project was completed while the first author was at Penn State University, from which he is currently on leave, and while the second author was visiting the Federal Reserve Bank of Dallas and Purdue University.

${ }^{2}$ Adle:t and Lehman (1983) and Stockman (1983) present evidence on real exchange rate changes for over 4.0 countries during both fixed and flexible exchange rate periods. Mussa (1986) examines relative prices and nominal exchange rates for 16 industrialized countries.

${ }^{3}$ Campbell and Clarida (1987) and Meese and Rogoff (1988) both reject the hypothesis that there is a significant statistical link between real exchange rates and real interest rate differentials, and relate their findings to sticky-price theories of the exchange rate. Edison and Pauls (1993) fail to find evidence of cointegration between real exchange rates and real interest rate differentials. Mark (1990) tests for unit roots and cointegration in exchange rates and price levels, finding evidence against PPP, and examines the implications for stylized versions of three popular exchange rate models. Baxter (1994) finds evidence that real interest rate differentials are related only to the temporary component of the the real exchange rate. This is consistent with Baxter (1993), which finds that several policy variables : Fail to explain a significant amount of real exchange rate movements. Engel (1993) shows that the variance of the common-currency price of the same good across borders is larger than the variance of the relative price of different goods within a country, and relates the results to the debate over sticky prices. In a similar vein, Engel and Rogers (1994) examine individual goods prices in U.S. and Canadian cities, in order to assess the relative importance of transportation costs, nontradeables, and sticky prices in explaining deviations from the law of one price. 
A second approach, to which our paper is more related, is to measure the relative importance of various shocks to the real exchange rate. Huizinga (1987) examines monthly data on the real exchange rates of the major industrial countries from 1974-86, and finds that on average the: variance of the permanent component accounts for $58 \%$ of the variance of the actual change in the real exchange rate. Baxter (1994) also analyzes the temporary and permanent components of real exchange rates, using a multivariate Beveridge-Nelson (1981) decomposition, and finds that most movements are due to changes in the permanent component. Following the methodology of: Blanchard and Quah (1989), as we do in this paper, Lastrapes (1992) and Clarida and Gali (1994) estimate the relative contribution of various shocks to explaining the variance of real exchange rates between the U.S. and Canada, Germany, Japan, Italy, and the U.K. ${ }^{4}$

The objective of our paper is to empirically assess the sources of movements in the real exchange rate between the U.S. and four high inflation countries - Argentina, Bolivia, Brazil and Israel. Our focus on these countries is motivated by several factors. First, the real exchange rate is a highly important variable in the above countries due to their size, openness, and dependence on a relatively thin export base. Adverse shocks to, or excessive variability in, the real exchange rate can have significant negative effects on output and employment. Second, these countries experienced relatively large movements in many of the economic variables purported to explain real exchange rate changes, suggesting that our focus may provide fertile ground for distinguishing among competing

${ }^{4}$ In Lastrapes' VAR, the variables are ordered $(\Delta \mathrm{R}, \Delta \mathrm{s})$, where $\mathrm{R}(\mathrm{s})$ is the real (nominal) exchange rate. The identifying restriction is thus that the long-run effect of the second (nominal) shock on the real exchange rate is zero. Depending on the exchange rate examined, the contribution of the real shock ranges from $63 \%$ to $94 \%$ at the one-month forecast horizon. The contribution is larger at longer horizons. Clarida and Gali (1994) estimate a more general system, $(\Delta y, \Delta R$, and $\pi)$, where $\mathrm{y}$ is the home-foreign output growth differential and $\pi$ is the inflation differential, with corresponding shocks labelled aggregate supply, aggregate demand, and nominal shocks. They find that nominal shocks account for between $34 \%$ and $47 \%$ of the variance of real exchange rate changes (over all horizons) for Germany and Japan, but no more than $2.8 \%$ for the U.K. and Canada. Essentially all of the rest is accounted for by aggregate demand shocks, as aggregate supply' shocks are negligible at all horizons for each country. 
explanations from theoretical exchange rate models. ${ }^{5}$ Third, several studies of PPP [Frenkel (1978), Krugman (1978), Taylor and McMahon (1988), and McNown and Wallace (1989)] have suggested that monetary factors are more important in high inflation episodes than for the low-inflation industrialized nations. We provide a framework for a precise quantification of this claim, which, to our kno'wledge, has not been undertaken.

Figure 1 contains plots of the real $(\mathrm{R})$ and nominal $(\mathrm{S})$ exchange rates for each of our four high inflation countries. Notice that the strong positive correlation between nominal and real exchange rates, found in the studies of low-inflation countries [e.g., see Mussa's (1986) Figures 1-8], appears only following the stabilization of these high inflation episodes. ${ }^{6}$ Our paper offers an explanation of why real and nominal exchange rates do not necessarily move together closely for the high inflation countries.

We attempt to be as precise as possible in identifying the shocks to the real exchange rate. Our benchmark three-variable model consists of permanent disturbances to government size, the real exchange: rate, and real money balances. These are interpreted as structural shocks - fiscal, output, and monetary shocks - based on a general-equilibrium optimizing model. To identify the system, we assume that all structural shocks are orthogonal. We also assume that a structural vector

\footnotetext{
${ }^{5} \mathrm{~A}$ useful distinction can be made between "disequilibrium" models of the exchange rate [Dornbusch (1976)], which imply that real exchange rate variation is due primarily to nominal disturbances, and "equilibrium" models [Stockman $(1980,1988)$ ], which rely on permanent, real shocks tc explain real exchange rate changes. This distinction is somewhat incomplete. Mussa (1982) examines exchange rate dynamics in a sticky-price model with traded and non-traded goods, allowing for both real and nominal shocks. Stockman and Ohanian (1993) analyze the effects of monetary policy on exchange rates in a two-sector model where prices are sticky in one sector and flexible in the other. Although our goal is not to test any particular model of exchange rates, our results have implications for the empirical validity of the different theories.

${ }^{6}$ The successful and ongoing stabilizations in this group include Bolivia and Israel beginning in mid-1985. Argentina's on-going stabilization began in April 1991, after our sample ends. Also, notice that the behavior of the real exchange rate is not markedly different during episodes of inflation/depreciation versus stabilization, except for Bolivia (and Israel to some extent). This apparent "invariance" of the real exchange rate with respect to the policy regime contrasts with the markedly different behavior of the real exchange rate under fixed versus floating exchange rate regimes found in studies of the industrialized countries.
} 
autoregression (VAR) representation of the data exists such that the moving average (MA) representation is fundamental. Furthermore, we follow the methodology of Blanchard and Cuah (1989) and Ahmed, Ickes, Wang and Yoo (1993) to impose two long-run restrictions: (i) long-run exogeneity of the government size and (ii) long-run monetary super-neutrality, by which we mean that changes in the money growth rate have no effect on government size, real output, and the real exchange rate in the long run. Both assumptions are consistent with a wide class of macroeconomic models. Recognizing the limitations of this empirical approach, which we address in Section 2.B, we estimate two additional four-variable models to demonstrate robustness.

Our main finding is that real exchange rate movements are strongly, though not exclusively, influenced by real shocks, especially those associated with restrictions on the flow of currency, income from foreign investments, capital, and/or goods. This is true of all countries in our sample, and even at short horizons. An extended discussion of the results is contained below. At a first pass, they suggest that traditional analyses of high inflation economies, especially those using the Cagan (1956) model, could be improved by allowing real shocks to play a role.

Although our long-run restrictions, exogenous government size and superneutrality of money, are fairly weak and ought to be unaffected by the choice of exchange rate regime, one might question our results on two related grounds. First, over the relatively short periods we study, our monetary shock may have "permanent" effects on the real exchange rate. Second, the literature on hysteresis suggests that large real exchange rate movements may result from purely nominal disturbances affecting the nominal exchange rate. ${ }^{7}$ These considerations imply that part of the "true" monetary shock may be incorrectly attributed to real shocks (output shocks or fiscal shocks). These considerations suggest that our results should be interpreted with some caution. However, they are

${ }^{7}$ For example, in Delgado (1991), optimizing firms do not change prices as often as the nominal exchange rate moves, and prices do not necessarily revert when the exchange rate returns to its initial level, because of menu costs. However, Stockman (1988) gives a skeptical view of the actual importance of the menu costs/hysteresis mechanism. Furthermore, within a wide range of alternative plausible assumptions on the interactions between the real and the monetary sectors, King and Watson (1992) find empirical evidence lending support to the hypothesis of long-run neutrality of money. 
unlikely to invalidate our main conclusion: analyses using Cagan-type models could be improved by including real shocks of the sort we discuss below.

\section{IDENTIFICATION AND DERIVATION OF THE MODEL}

We first discuss the long-run nature of the identifying restrictions. ${ }^{8}$ We derive a "benchmark", three-variable model that includes the real exchange rate and fiscal and monetary variables, and give a theoretical justification for interpreting the structural shocks. This highlights the long-run restrictions used to estimate these shocks, as in Blanchard and Quah (1989), Ahmed, Ickes, Wang, and Yoo (1993), and Rogers and Wang (1993). Because most macroeconomic debates are about short-run phenomena, it is generally less controversial to use long-run rather than short-run restrictions. In particular, it is possible to select a set of long-run restrictions that can be used for both fixed and flexible exchange rate regimes. We also address critiques of this empirical approach.

\section{A. Identifying the Benchmark Model}

Consider a vector of stationary variables $\mathrm{X}$ and a vector of structural shocks $\epsilon$. The structural model can be compactly written,

$$
X_{t}=C(L) \epsilon_{t}
$$

where $\mathcal{C}$ is a non-singular matrix of coefficients, and $L$ denotes the lag operator. An estimatible reduced form of the structural system is given by,

$$
\Gamma(\mathrm{L}) \Delta \mathrm{X}_{\mathrm{t}}=\Phi \mathrm{X}_{\mathrm{t}-1}+\epsilon_{\mathrm{t}}^{*} .
$$

Assume the MA representation to be fundamental in the sense that all structural disturbances can be recovered as one-sided convergent distributed lags in observable variables [see Blanchard and Quah (1993)]. Furthermore, assume that the long-run moving average coefficient matrix, C(1), is lowertriangular and that the elements of $\epsilon$ are mutually uncorrelated. We can then follow the procedure developed by Ahmed, Ickes, Wang, and Yoo (1993) to retrieve the "structural" coefficients from the

\footnotetext{
${ }^{8}$ Notably, the "long run" is a hypothetical concept, defined as one such that the causal ordering is satisfied. It is not made in reference to the length of the sampling interval.
} 
reduced form VAR. This recovering process is unique as long as the signs of the diagonal elements of $\mathrm{C}(1)$ are fixed by the theoretical model.

Consider the vector of stationary variables $X=\{\Delta(\mathrm{g} / \mathrm{y}), \Delta \ln (\mathrm{R}), \Delta \ln (\mathrm{m})\}$ and the vector of shocks $\epsilon=\left\{\epsilon^{\mathrm{g}}, \epsilon^{\mathrm{y}}, \epsilon^{\mu}\right\}$. Here $\mathrm{g}$ denotes the real value of government spending, $\mathrm{y}$ is real outpul., $\mathrm{R}$ is the real exchange rate (the nominal exchange rate in domestic currency per U.S. dollars, $s$, times the U.S. price level divided by the domestic price level), and $\mathrm{m}$ is real money balances. The three structural shocks are, in order, permanent disturbances to government size, to the real exchange rate, and to real money balances. These will be interpreted as structural shocks, namely fiscal, output and monetary disturbances, based on the theoretical model in Section 2.C below. The three transformed variables are assumed to be related in the long run as follows:

$$
\left[\begin{array}{c}
\Delta(\mathrm{g} / \mathrm{y}) \\
\Delta \ln (\mathrm{R}) \\
\Delta \ln (\mathrm{m})
\end{array}\right]=\left[\begin{array}{c}
\overline{\mathrm{g}} \\
\mathrm{R} \\
\dot{\mathrm{m}}
\end{array}\right]+\left[\begin{array}{ccc}
\mathrm{C}_{11} & 0 & 0 \\
\mathrm{C}_{21} & \mathrm{C}_{22} & 0 \\
\mathrm{C}_{31} & \mathrm{C}_{32} & \mathrm{C}_{33}
\end{array}\right]\left[\begin{array}{l}
\epsilon^{\mathrm{g}} \\
\epsilon^{\mathrm{y}} \\
\epsilon^{\mu}
\end{array}\right]
$$

where $\overline{\mathrm{g}}, \mathrm{R}$, and $\overline{\mathrm{m}}$ are constant and independent of the structural shocks.

We deduce the theoretically expected signs of the elements of the three-by-three matrix, $C(1)$, from the illustrative model that follows, but first give a general justification for its lower triangularity. The zero-restrictions in the top row reflect the assumption that the long-run size of government is exogenous. The remaining zero-restriction, in row two and column three of $\mathrm{C}(1)$, implies that the real exchange rate is unaffected by the monetary shock in the long run (i.e., long-run superneutrality of money). The lower triangularity of $\mathrm{C}(1)$ and the assumed orthogonality property of the shocks enables us to identify the structural disturbances.

\section{B. Methodological Issues}

Before proceeding further, it is worthwhile discussing some of the critiques of the emp irical approach adopted here. First, as pointed out by Lippi and Reichlin (1993), we must assume that the 
MA representation is fundamental since otherwise the structural VAR methodology would be improper. Blanchard and Quah (1993) emphasize that this assumption is required in standard macroeconometric work and is made implicitly in most time-series empirical studies. In other words, ruling out nonfundamental MA representations is common in practice.

Second, Faust and Leeper (1994) critically address the validity of imposing the long-run restrictions and the implicit aggregation of shocks in the Blanchard-Quah methodolgy. Both concerns motivate: our robustness checks. Because we are imposing infinite order (long-run) restrictions on a finite order VAR, the estimation results are correct only if the estimated reduced-form VAR is the correct representation. In this sense, imposing long-run restrictions is not necessarily more robust to possible misspecification than imposing short-run restrictions as in Bernanke (1986). ${ }^{9}$ As pointed out by Blanchard and Quah (1989) and elaborated upon by Faust and Leeper (1994), if one identified structural shock indeed consists of two independent shocks, then the methodology is valid only if the underlying macroeconomic variables respond to the two shocks in the same directions.

In practice we can only consider a limited set of variables identifying a limited set of shocks. Because many theoretical models suggest that fiscal and output shocks lead to opposite effects on the real exchange rate, it is crucial to separate the two, as in our three-by-three benchmark model. Of course, one may argue that the "output" shock consists of both aggregate demand and aggregate supply shocks and the "monetary" shock contains both money demand and money supply shocks. These disaggregated shocks will affect the real exchange rate differently. As a consequence, we provide a sensitivity analysis in the four-by-four alternative- 1 model, in which a "preference" or "demand" shock is separately identified from the output "supply" shock based on the assumption that output is supply-determined in the long run. Finally, we decompose the "nominal" shock into monetary and exchange rate shocks in the four-by-four alternative- 2 model. This exercise is useful in

${ }^{9}$ Our methodology is less controversial in the sense that it provides the reduced-form VAR with a structural interpretation based on a theory that is consistent with a wider class of macroeconomic models, as compared to alternative methods. 
understanding monetary policy when there is a heavy degree of exchange-rate management. We believe these models have exhausted the most important underlying forces in real exchange rate: movements. Any further expansion of the system will reduce the degrees of freedom without improving the model structure significantly.

\section{Interpreting the Shocks: An Illustrative Long-Run Model}

In order to illustrate how the residuals in our system may be interpreted as structural shocks, we develop the following continuous-time, rational-expectations model with infinitely-lived firrns and consumers. We choose this framework to elaborate the benchmark model because it is tractable and not implausible in mimicking long-run optimizing behavior in a small, open monetary economy. We note that this model is used for expository purpose and that there is a wide class of open macro models with long-run properties consistent with those derived below. ${ }^{10}$ Readers who already buy into the identifying restrictions and wish to skip directly to the results in section 3 , can do so without great loss to continuity.

Consider a stylized dynamic model of a small open economy in which the infinitely lived representative consumer with perfect foresight decides the optimal composition of consumption of nontraded and traded goods, $\mathrm{c}^{\mathrm{N}}$ and $\mathrm{c}^{\mathrm{T}}$, respectively. For analytical convenience, we take labor: force in both nontraded and traded goods industries, $n^{N}$ and $n^{T}$, to be stationary: $n^{N}=B^{N} \exp \left(b^{N} t\right)$ and $n^{T}=$ $B^{T} \exp \left(b^{T} t\right)$, where $B^{N}, B^{T}, b^{N}$, and $b^{T}$ are treated as parametrically given. Thus, we can express output of nontraded and traded goods, $\mathrm{y}^{\mathrm{N}}$ and $\mathrm{y}^{\mathrm{T}}$, as:

$$
y^{N}=A\left(n^{N}\right)^{v} ; \quad y^{T}=A^{\phi}\left(n^{T}\right)^{v}
$$

where $\mathrm{A}$ is the productivity measure reflecting changes in technology, $0<\nu<1$, and where $\phi>1$, indicating that traded goods production is more sensitive to technological changes. In the absence of a labor-leisure trade-off, output is therefore exogenous. This captures the fundamental feature that

\footnotetext{
${ }^{10}$ This would include long-term labor contract, monetary business cycle, real business cycle, efficiency wage, menu cost and adjustment cost models, in which money may be introduced via the utility or production function, a transactions-cost technology or a cash-in-advance constraint.
} 
equilibrium output is supply-determined in the long run, as is consistent with our focus on the model's long-run properties. ${ }^{11}$

Define the real exchange rate as $\mathrm{R} \equiv s \mathrm{P}^{\mathrm{T}} / \mathrm{P}^{\mathrm{N}}$, where s denotes the nominal exchange rate (domestic currency per unit of U.S. currency) and $\mathrm{P}^{\mathrm{N}}$ and $\mathrm{P}^{\mathrm{T}}$ are the monetary prices of nontraded and traded goods, respectively. Let $\pi$ be the rate of change of $\mathrm{P}^{\mathrm{N}}$ and for simplicity assume $\mathrm{P}^{\mathrm{T}}$ to be constant over time. Furthermore, denote $\mathbf{M}$ and $\mathbf{M}^{*}$, respectively, as the nominal stock of domestic and foreign (U.S.) currency. Then real values of domestic and foreign currencies can be defined in units of U.S. currency: $m \equiv M /\left(s P^{T}\right)=\left(M / P^{N}\right) / R$ and $m^{*} \equiv M^{*} / P^{T}$.

The representative agent solves the following optimization problem:

$$
\max \int_{0}^{\infty}\left[\alpha \ln c^{N}(t)+(1-\alpha) \theta \ln c^{T}(t)\right] e^{-\rho t} d t
$$

subject to

$$
\begin{gathered}
c^{N} / R+c^{T}+\dot{m}+\dot{m}^{*}=(1-\tau)\left(y^{N} / R+y^{T}\right)-\pi m+h \\
c^{N} / R+c^{T} \leq \beta m^{\gamma}\left(m^{*}\right)^{1-\gamma},
\end{gathered}
$$

where $\rho>0$ is the rate of time preference, $\mathrm{h}$ is a lump-sum real money transfer, $\tau$ is the general income tax rate, $0<\alpha<1, \beta>0$, and $0<\gamma<1$. Finally, $\theta$, a shift parameter that captures changes in preferences toward the traded good, is assumed to be a positive constant for the moment. This assumption is relaxed in our $4 \times 4$ alternative- 1 model. While (5) is a standard budget constraint, (6) formulates a generalized cash-in-advance constraint in which the righthand side measures the cash services required for consumption purchases. Specific functional forms for the preference and monetary transactions technologies simplify the analytical expressions, but are not necessary for obtaining the long-run implications of the model.

\footnotetext{
${ }^{11}$ Allowing for an endogenous labor-leisure trade-off and endogenous capital accumulation will not alter the long-run properties derived below, as long as leisure is separable from consumption and the productivity factor is multiplicative.
} 
Denote $\lambda_{1}$ as the co-state variable to $\mathrm{m}$ and $\mathrm{m}^{*}$ and $\lambda_{2}$ as the multiplier associated with (6).

Then the first-order conditions for the above optimization problem are:

$$
\begin{gathered}
\alpha / \mathrm{c}^{\mathrm{N}}=\left(\lambda_{1}+\lambda_{2}\right) / \mathrm{R} \\
(1-\alpha) / \mathrm{c}^{\mathrm{T}}=\left(\lambda_{1}+\lambda_{2}\right) \\
\dot{\lambda}_{1}=(\rho+\pi) \lambda_{1}-\lambda_{2} \beta \gamma\left(\mathrm{m} / \mathrm{m}^{*}\right)^{-(1-\gamma)} \\
\dot{\lambda}_{1}=\rho \lambda_{1}-\lambda_{2} \beta(1-\gamma)\left(\mathrm{m} / \mathrm{m}^{*}\right)^{\gamma} .
\end{gathered}
$$

Here, (7a) and (7b) reflect intertemporal consumption efficiency for nontraded and traded goods, whereas (7c) and (7d) govern the evolution of the shadow values of domestic and foreign currencies, respectively. Straightforward steady-state analysis implies $\pi=\mu$ and $\mathrm{h}=\mu \mathrm{m}$, thus leading to

$$
\begin{gathered}
\mathrm{c}^{\mathrm{N}}=(1-\tau) \mathrm{y}^{\mathrm{N}}, \quad \mathrm{c}^{\mathrm{T}}=(1-\tau) \mathrm{y}^{\mathrm{T}} \\
\mathrm{m} / \mathrm{m}^{*}=[\gamma /(1-\gamma)] \rho /(\rho+\mu)
\end{gathered}
$$

where the latter equation determines the optimal portfolio between domestic and foreign currencies, which depends negatively on the inflation rate differential (captured by $\mu$ ).

Substituting ( $8 a$ ) and (7b) into (7a), we can derive the real exchange rate as:

$$
R=\theta[(1-\alpha) / \alpha]\left(y^{N} / y^{T}\right)
$$

which, together with (8a), (8b) and a binding cash-in-advance constraint (i.e., (6) with equal ty), yield

$$
\mathrm{m}=[\beta \theta(1-\alpha)]^{-1}[\gamma /(1-\gamma)]^{1-\gamma}(1-\tau)[\rho /(\rho+\mu)]^{1-\gamma} \mathrm{y}^{\mathrm{T}}
$$

Let $g$ denote real government spending and $(g / y)$ measure government size (i.e., the government spending to output ratio). Assume for the moment that the government purchases uniformly from the nontraded and traded sectors. In equilibrium, a balanced government budget implies that ( $\mathrm{g} / \mathrm{y}$ ) must be equal to the general income tax rate, i.e., $(g / y)=g /\left(y^{N} / R+y^{T}\right)=\tau$. We assume that 
government size is exogenously determined, following a random walk. ${ }^{12}$ That is, we can specify the fiscal shock as

$$
\Delta(\mathrm{g} / \mathrm{y})=\mathrm{e}^{\mathrm{g}},
$$

where $\epsilon^{\mathrm{g}}$ is white noise.

Next specify the money growth shock as $\Delta \mu=\delta^{\mu}+\epsilon^{\mu}$ and the technology shock as $\Delta \ln (\mathrm{A})=\delta^{y}+\epsilon^{y}$. These specifications imply that money growth and productivity follow a random walk with drift, where $\epsilon^{\mu}$ and $\epsilon^{y}$ are white noise and $\delta^{\mu}$ and $\delta^{y}$ are the drift terms. By approximation, $\Delta \ln (1-\tau) \approx-\Delta \tau=-\Delta(\mathrm{g} / \mathrm{y})=-\epsilon^{\mathrm{g}}$ and $\Delta \ln (1+\mu / \rho) \approx \Delta \mu / \rho=\left(\delta^{\mu}+\epsilon^{\mu}\right) / \rho$. Differencing (9) and (10) and using (4) yields (aside from the deterministic trends):

$$
\begin{gathered}
\Delta \ln (\mathrm{R})=\mathrm{R}_{0}-(\phi-1) \epsilon^{\mathrm{y}} \\
\Delta \ln (\mathrm{m})=\mathrm{m}_{0}-\epsilon^{\mathrm{g}}+\phi \epsilon^{\mathrm{y}}-[(1-\gamma) / \rho] \epsilon^{\mu},
\end{gathered}
$$

where $\mathrm{R}_{\mathrm{c}}=-(\phi-1) \delta^{y}$ and $\mathrm{m}_{0}=\phi \delta^{y}-[(1-\gamma) / \rho] \delta^{\mu}$. Thus, a positive shock to government size or to money supply growth results in a lower demand for domestic currency. While a positive output shock increases domestic money demand, it also causes an appreciation of the real exchange rate (i.e., a decrease in R). Notice that since traded and nontraded goods are taxed equally and government purchases from the two sectors are uniform, the fiscal policy shock does not affect the real exchange rate in the long run. To the extent that this is not true in practice, it suggests that fiscal shocks in general will affect the real exchange rate. Since in reality traded goods are taxed more heavily (under the consideration of tariffs) and government consumption consists of more non-traded goods, a larger government size is expected to lead to a real exchange rate depreciation. With this in mind, equation system ( 11$)-(13)$ can be used to justify the restricted long-run model for the structural VAR estimation as specif ed in (3), and then extended as in (3)' below.

\footnotetext{
${ }^{12}$ This is consistent with the empirical study of Ahmed and Yoo (1992). Notice that random walklike behavior for $(\mathrm{g} / \mathrm{y})$, at least within the bounds, is not ruled out simply because $(\mathrm{g} / \mathrm{y})$ is bounded.
} 


\section{RESULTS}

\section{A. Unit Roots and Cointegration}

Before proceeding with the VAR analysis, we first present evidence concerning the time-series properties of all the variables. Chart 1 summarizes the data. All experienced a hyperinflation (or approached very close to it) for some short periods. Also note that our sample periods inclucle both high inflation and stabilization data.

For the unit roots tests, we use (i) both $\tau_{\mu}$ and $\tau_{\tau}$ Augmented Dickey-Fuller (ADF) tesits to test the null hypothesis of $\mathrm{I}(1)$ versus $\mathrm{I}(0)$, and again to test $\mathrm{I}(2)$ versus $\mathrm{I}(1)$; and (ii) $95 \%$ confidence intervals for the largest autoregressive root, which are constructed from the ADF statistics using Stock's (1991) procedure. As seen in table 1, the ADF test statistics indicate that, with perhaps one or two exceptions, the variables can be characterized as follows:
(i) $\underline{\text { (1) variables - }}(\mathrm{g} / \mathrm{y}), \ln (\mathrm{R}), \ln (\mathrm{m}), \ln (\mathrm{y})$;
(ii) I(2) variable - $\ln (\mathrm{s})$.

As for the possible exceptions, it appears that $\ln (\mathrm{y})$ is $\mathrm{I}(0)$ for Argentina, $(\mathrm{g} / \mathrm{y})$ is $\mathrm{I}(0)$ for Brazil, and,

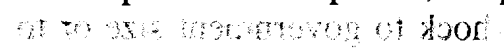
perhaps, that Brazilian $\ln (\mathrm{s})$ is trend-stationary in the growth rate. We elaborate on this next

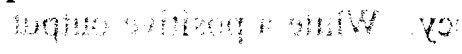

In a recent paper, Stock (1991) quantifies the uncertainty associated with unit roots tests, while maintaining the classical approach to testing, by constructing confidence intervals for the largest autoregressive root of a time series when this root is close to unity. Following Stock's procedure, we report $95 \%$ confidence intervals for each of our test statistics in Table 1. Many of the intervals are wide. For one borderline case, $\Delta \ln (s)$ for Brazil, the data are consistent with the hypothesis that the

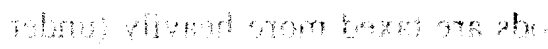
process is $\mathrm{I}(1)$, but are also consistent with the hypothesis of trend stationarity with an autoregressive root of 0.59 . The most objectionable departure from the characterization of the stochastic processes outlined above is for Argentine $\ln (\mathrm{y})$ and Brazilian (g/y), which appear to be trend-stationary. We account for this as we proceed with the VAR analysis. ${ }^{13}$

\footnotetext{
${ }^{13}$ In the VARs to follow, we make Argentine $\ln (\mathrm{y})$ and Brazilian $(\mathrm{g} / \mathrm{y})$ stationary by removing a linear deterministic time trend rather than by first-differencing. We checked the sensitivity of our results to moving the detrended variable last in the VAR to allow all shocks to affect the deviation of the trend-stationary variable from the deterministic trend. The results are not qualitatively different.
} 
In Table 2, we show that Johansen's (1991) test fails to reject the null of no cointegration at $5 \%$ for each system in all countries except the four-by-four system $[(\mathrm{g} / \mathrm{y}), \ln (\mathrm{R}), \ln (\mathrm{m}), \Delta \ln (\mathrm{s})]$ for Bolivia. Checking the sensitivity of results to changes in lag length, intially set at 4 , however, we find that the null of no cointegration cannot be rejected for the Bolivian system when 3 lags are used, as shown in Table 2. Because of the borderline nature of the rejections we do obtain, we proceed with the assumption of no cointegration for all systems. ${ }^{14}$

\section{B. Results for the Benchmark Model}

Table 3 presents the results from estimating the three-variable VAR model, consisting of government size, the real exchange rate, and real money balances. Notice first that, across all countries, each of the elements of the $\mathrm{C}(1)$ matrix given by equation (3) has the predicted sign. Of particular irnportance, $\mathrm{C}_{21}$ is positive and $\mathrm{C}_{22}$ is negative, implying that fiscal shocks lead to a longrun real depreciation and output shocks lead to a long-run real appreciation. Furthermore, the $\mathrm{C}_{31}$, $\mathrm{C}_{32}$ and $\mathrm{C}_{33}$ coefficients imply that, for all four countries, the output shock has a positive effect on real money balances in the long run, while fiscal and monetary shocks have a negative long-run effect. This is consistent with traditional money demand functions.

The VDC results indicate that output shocks have the most influence on $\Delta \ln (\mathrm{R})$, averaging at the first (4-year) horizon $80 \%(64 \%)$ across the four countries. Fiscal and monetary shocks are also influential in some cases. For Bolivia and Israel, where the correlation between real and nominal exchange rates is highest among our countries, monetary shocks contribute $22.3 \%$ and $45.0 \%$, respectively, to the variance of real exchange rate changes in the long run. The contribution of monetary shocks is not as large in Argentina and Brazil.

The: IRFs are displayed in Figure 2. First, the effect of the output shock on the real exchange rate is significantly negative (i.e., causes a real appreciation of the domestic currency) and longlasting in all cases. The cumulative effects are hump-shaped for Bolivia and Brazil, and continuously

\footnotetext{
${ }^{14}$ Notice that we do not undertake estimates for the Argentine 4-by-4 system with output, or the Brazilian sy/stems, because of the results of the unit roots tests.
} 
expanding for Argentina and Israel. Second, with up to a one year lag, monetary shocks lead to significant real exchange rate depreciation in Bolivia, Brazil and Israel. Such an effect, however, is instantaneous and significant in Argentina, Finally, the positive short-run effect of a fiscal expansion implies a real depreciation. In our model, this is consistent with government levying taxes (tariffs) more heavily on tradeables than non-tradeables and/or government consumption consisting of relatively more non-tradables than tradeables.

\section{Decomposing the Output Shock: Results for the Alternative-1 Model}

In recognizing that aggregate demand and supply shocks generate very different effects on the real exchange rate, we first expand the three-by-three benchmark model by separately identifying a demand shock from the output supply (technological) shock. This is done by relaxing the assumption that the preference shift parameter, $\theta$, is a constant; instead, we assume $\Delta \ln (\theta)=\epsilon^{\mathrm{d}}$, wher $\epsilon \epsilon^{\mathrm{d}}$ is a demand or preference shock (toward the traded good). Since equilibrium output is supplydetermined, the preference shock will not affect output in the long run, but will lead to a real exchange rate depreciation and a lower demand for domestic currency [see equations (9) and (10)].

With this change in the theoretical model, we can extend the three-by-three system to a fourby-four system consisting of the four (stationary) variables $\{\Delta(\mathrm{g} / \mathrm{y}), \Delta \ln (\mathrm{y}), \Delta \ln (\mathrm{R}), \Delta \ln (\mathrm{m})\}$ and four corresponding shocks $\left\{\epsilon^{\mathrm{g}}, \epsilon^{\mathrm{y}}, \epsilon^{\mathrm{d}}, \epsilon^{\mu}\right\}$ :

$$
\left[\begin{array}{c}
\Delta(\mathrm{g} / \mathrm{y}) \\
\Delta(\mathrm{y}) \\
\Delta(\mathrm{R}) \\
\Delta(\mathrm{m})
\end{array}\right]=\left[\begin{array}{c}
\overline{\mathrm{g}} \\
\overline{\mathrm{y}} \\
\mathrm{R} \\
\overline{\mathrm{m}}
\end{array}\right]+\left[\begin{array}{cccc}
\mathrm{c}_{11} & 0 & 0 & 0 \\
\mathrm{c}_{21} & \mathrm{c}_{22} & 0 & 0 \\
\mathrm{c}_{31} & \mathrm{c}_{32} & \mathrm{c}_{33} & 0 \\
\mathrm{c}_{41} & \mathrm{c}_{42} & \mathrm{c}_{43} & \mathrm{c}_{44}
\end{array}\right]\left[\begin{array}{l}
\epsilon^{\mathrm{g}} \\
\epsilon^{\mathrm{y}} \\
\epsilon^{\mathrm{d}} \\
\epsilon^{\mu}
\end{array}\right]
$$

where the first vector on the right hand side contains constant terms that are independent of the structural shocks. According to the modified theoretical model, the long-run multipliers are: $\mathrm{C}_{11}=1, \mathrm{C}_{21}=0, \mathrm{C}_{22}=1, \mathrm{C}_{31}=0, \mathrm{C}_{32}=-(\phi-1), \mathrm{C}_{33}=1, \mathrm{C}_{41}=-1, \mathrm{C}_{42}=\phi, \mathrm{C}_{43}=-1$ and 
$\mathrm{C}_{41}=-\left[\left(1-\gamma^{\prime}\right) / \rho\right]$. For the purpose of estimation, we generalize this model in the following way. As argued above, if the traded good is taxed more heavily than non-traded goods or if government consumption consists of more nontraded goods, $\mathrm{C}_{31}$ will be positive, implying that a permanent fiscal expansion will lead to a long-run depreciation of the real exchange rate. Moreover, if one allows for non-optimizing government activities, $\mathrm{C}_{21}$ is likely to be different from zero. In the estimation, the over-identifying restrictions above are not imposed.

This modification enables us to separate aggregate demand and supply shocks. In particular, the two shocks associated with y and $\mathrm{R}$, labelled $\epsilon^{\mathrm{y}}$ and $\epsilon^{\mathrm{d}}$, can be interpreted, respectively, as aggregate supply (technological) and aggregate demand (preference) disturbances. In the illustrative theory model, the demand shock measures the preference shift toward the traded good. In practice, such a shock will include government trade and financial restrictions that induce households to shift from non-traded to traded goods, thereby altering the relative price of traded and nontraded goods.

The results for this model are presented in Table 4. The coefficients of the long-run moving average ma:rix are generally of the sign predicted by the model. Turning to the VDCs, notice that the contributions of the fiscal shock and the monetary shock are approximately the same as they are in the benchmark model. For example, the contribution of the monetary shock at the 4-year horizon for Argentina, Bolivia, Brazil, and Israel, respectively, is $(10.2,20.1,19.9$, and 46.7) in the 4-by-4 model and $(6.06,22.3,16.9$, and 45.0$)$ in the three-variable benchmark model.

Interestingly, the VDCs indicate that relatively more of contribution of the combined output shock is due to aggregate demand. Consider Argentina. At the 4-year horizon, the contribution of the combined output shock in the benchmark model is $74.2 \%$, as reported in Table 3. According to Table 4 , the contribution of the aggregate supply shock is $23.2 \%$ and the contribution of the aggregate demand shock is $46.3 \%$. For Bolivia, the analogous figures are $67.7 \%$ for the combined output shock in the 3-by-3 model, $15.2 \%$ for the AS shock in the 4-by-4 model, and $49.8 \%$ for the AD shock in the 4-by-4 model; for Brazil and Israel, respectively, they are $70.2 \%$ (combined), 
$10.8 \%$ (AS), $59.4 \%(\mathrm{AD})$, and $44.9 \%$ (combined), $4.90 \%$ (AS), and $42.0 \%$ (AD). Aggregate demand shocks are even more important at shorter horizons. The relatively important role of AD shocks in our estimates is consistent with the results that Clarida and Gali (1994) found for Japan, Germany, the U.K., and Canada. However, aggregate supply (productivity) shocks are considerably more important in our estimates than in Clarida and Gali (1994), who find essentially no effect from such shocks at any horizon for any of their countries.

The IRFs are reported for all countries at the end of Table 4. To save space, we display graphically only the results for Israel in Figure 3. As with the benchmark model, the fiscal shock gives rise to a permanent real depreciation, while the monetary shock produces a temporary real appreciation. As anticipated, the aggregate supply shock gives rise to a real appreciation, which is significant at short horizons, while the aggregate demand shock produces a real depreciation. Notice from the bottom of Table 4 that the aggregate demand is the most influential shock for all sountries, as is true of the VDCs.

Because the "preference", or aggregate demand, shock is the single most influential. shock, it is useful to discuss more completely the types of disturbances that fall into this category in practice. Wars would induce a change in preferences for tradeables relative to non-tradeables, and may have been important for some of our countries. More importantly, we suspect, are government policy restrictions on the free flow of currency, income from foreign investments, capital, and/or goods, of the type analyzed by Stockman and Hernandez (1988). To the extent that such policy restrictions affect relative goods demand and hence relative prices, but do not affect government size or output in the long run, they are appropriately interpreted as included in the third system shock.

\section{Decomposing the Nominal Shock: Results for the Alternative-2 Model}

We also expand the three-by-three benchmark model along another dimension by decomposing the last, "nominal" shock into a pure monetary disturbance and a nominal exchange rate disturbance. As long as the long-run neutrality assumption is continuously imposed, we can simply attach the 
stationary form of the nominal exchange rate to the three-variable VAR: $\{\Delta(\mathrm{g} / \mathrm{y}), \Delta \ln (\mathrm{R}), \Delta \ln (\mathrm{m})$, $\left.\Delta^{2} \ln (\mathrm{s})\right\}$. Of course, the shocks to $(\mathrm{g} / \mathrm{y})$ and $\mathrm{R}$ are still the fiscal shock and the output shock. In addition, the shock to $\mathrm{m}$ is the pure monetary shock $\left(\epsilon^{\mu}\right)$, while the shock to $\mathrm{s}$ reflects disturbances to the nominal exchange rate $\left(\epsilon^{s}\right)$, such as those due to central bank intervention. Note that a positive $\epsilon^{s}$ shock indiccites a nominal depreciation (i.e., an increase in s); thus, the long-run multiplier $\mathrm{C}_{44}$ is taken to be positive. The long-run effect of $\epsilon^{y}\left(C_{42}\right)$ is expected to be negative, as higher domestic output leads to increased demand for domestic money and a nominal appreciation. On the other hand, the long-run effect of $\epsilon^{\mu}\left(\mathrm{C}_{43}\right)$ is expected to be positive, as domestic monetary expansion results in a nominal depreciation. However, even if traded goods are taxed more heavily than non-tradeables, or if the goverrmment purchases more nontraded goods, the long-run effect of $\epsilon^{g}\left(C_{41}\right)$ would still be ambiguous. The ambiguity arises from the opposing effects of the shock on the expected inflation rate versus the real interest rate. If one believes that the expected inflation effect dominates in the long run, then $\mathrm{C}_{41}$ is likely to be positive.

According to Table 5, the coefficients of the long-run moving average matrix are once again generally of the sign predicted by the model. Our VDC results, also in Table 5, indicate that the contributions of the combined monetary-nominal exchange rate shock range from $13 \%$ in Argentina to just under one-half in the rest of the countries at the 4-year horizon. In Argentina and Israel, nominal exchange rate disturbances account for an insignificant portion of the variance of real exchange rate changes. The impulse response functions, given at the bottom of Table 5 for all countries, but displayed graphically only for Israel in Figure 4, are very similar to those of the benchmark model. This is to be expected since the first three shocks of the new model have very similar interpretations to those of the benchmark model.

Finally, the alternative- 2 model also enables us to examine the major factors driving movements in the nominal exchange rate. We find that at all horizons, over half of the variance of nominal exchange rate changes are due to the combined monetary-nominal exchange rate shocks in 
these four high-inflation countries. This indicates that the nominal exchange rate does depend crucially on monetary disturbances, consistent with traditional beliefs.

\section{E. Further Discussion}

In closing, three points are worth mentioning. First, for a given country, the contribution of the disturbance to real money balances, $\epsilon^{\mu}$, to the variance of the real exchange rate is very similar across all three models. As seen in Tables 3-5, at the 4-year horizon the contribution of $\varepsilon^{\mu}$ is, under the three specifications (benchmark, alternative-1, alternative-2) respectively, $(6.06,10.2,4.48)$ for Argentina, $(22.3,20.1,29.2)$ for Bolivia, $(16.9,19.9,27.9)$ for Brazil, and $(45.0,46.7,45.6)$ for Israel. We find this reassuring in light of recent criticisms of the VAR methodology.

Second, by comparing the output shock $\left(\epsilon^{y}\right)$ in the benchmark model with the combined aggregate supply and aggregate demand shocks $\left(\epsilon^{y}+\epsilon^{d}\right)$ in the alternative-1 model, we find that their contributions in explaining the real exchange rate movements for a given country are alsc very similar. As shown in Tables 3 and 4, at the 4-year horizon, the contribution of $\epsilon^{y}$ in the benchmark model and $\epsilon^{y}+\epsilon^{d}$ in the alternative-1 model, respectively, is $(74.2,69.5)$ for Argentina, $(57.7,65.0)$ for Bolivia, $(70.2,70.2)$ for Brazil and $(44.9,46.9)$ for Israel. The magnitude of this effect across countries suggests that, even though our empirical methodology may be subject to some sriticism, our main conclusion regarding the importance of real shocks in driving real exchange rate flutuations should not be invalidated.

Third, motivated by the results in Faust and Leeper (1994) showing the fragility of Blanchard and Quah's (1989) results to changes in the variable representing the nominal disturbance;, we examine a variant of the alternative- 2 model, replacing the exchange rate with the price level. Thus, the new model is $\left\{\Delta(\mathrm{g} / \mathrm{y}), \Delta \ln (\mathrm{R}), \Delta \ln (\mathrm{m}), \Delta^{2} \ln (\mathrm{p})\right\}$. This has no qualitative, and only a very small quantitative, effect on the results we saw in Table 5. For example, at the 4-year horizon for Argentina, the effect on $\Delta \ln (R)$ of each shock in is, in order, $(25.5,63.0,7.50,4.01)$. As seen in Table 5, this is quite close to the corresponding magnitudes in the model with the nominal exchange 
rate: $(24.9,61.8,7.50,4.48)$. Similar results hold for Bolivia $(16.4,35.7,35.6,12.3)$ [in the model with p] versus $(23.4,31.8,29.2,15.6)$ [model with s], and for Israel $(5.64,48.7,43.9,1.74)$ [model with p] versus $(3.39,50.2,45.6,0.79)$ [model with s], but there are some differences for Brazil: $(17.1,11.4,18.0,53.4)$ versus $(7.48,43.6,21.0,27.9)$, where the contribution of the two real shocks (combined) is apparently somewhat smaller for the estimate using the price level.

\section{Conclusions}

This paper empirically assesses the sources of fluctuations in the real exchange rates of four high inflation countries, by imposing long-run identifying restrictions based on a general-equilibrium dynamic monetary model. In contrast to conventional beliefs about the relative importance of real and monetary shocks for high inflation countries, we find that real exchange rate movements are mostly driven by real shocks. Since the nominal exchange rate depends mostly on monetary disturbances, our results explain why real (R) and nominal (S) exchange rates do not necessarily move together closely during these high inflation episodes (Figure 1). Only for Israel and Bolivia is there a positive correlation over a prolonged period between $\mathrm{R}$ and $\mathrm{s}$. According to our analysis, this observation is consistent with the monetary shock accounting for a relatively large share of the variance of the real exchange rate only for Israel and Bolivia.

An important part of our strategy is to test the robustness of these findings. The intial threeby-three spe:cification has the advantage of parsimony, and provides a useful benchmark. Results from the extended four-by-four systems are found to be broadly consistent with those from the benchmark rnodel. The extended models are undertaken in the spirit of Faust and Leeper's (1994) findings concerning the aggregation of multiple shocks. They have an advantage over the benchmark model in that they allow for additional insights into the separate effects of (i) aggregate supply versus aggregate demand effects and (ii) different types of monetary disturbances, on the real exchange rate. We believe that the models in Section 3 exhaust the set of feasible specifications for our episodes. 
We emphasize that even if one questions our results on the grounds that money growth shocks may produce permanent effects on the real exchange rate, it is hard not to be impressed by the estimated magnitude of the effects of real shocks. Hence, we argue that the possibility thit money growth shocks are not super-neutral does not invalidate our main conclusion that analyses using Cagan-type models could be improved by including real shocks. It would be useful to study the behavior of real exchange rates in high inflation economies using models which emphasize the effects of real shocks -- such as government policy restrictions on the flow of currency, income from foreign investments, capital, and/or goods -- in addition to sticky prices and monetary shocks. Progress along these lines has recently been made by Stockman and Ohanian (1993). 


\section{REFERENCIES}

Adler, Michael, and Bruce Lehman, 1983. "Deviations from Purchasing Power Parity in the Long Run," Journal of Finance (December) 1471-1486.

Ahmed, Shaghil, Barry Ickes, Ping Wang, and Sam Yoo, 1993. "International Business Cycles," American Economic Review (June), 335-359.

Ahmed, Shaghil, and Sam Yoo, 1992. "Fiscal Trends," Journal of Money, Credit and Banking, forthcoming.

Baxter, Mariınne, 1993. "Real Exchange Rates, Real Interest Rates, and Government Policy: Theory and Evidence," mimeo, University of Virginia.

Baxter, Marianne, 1994. "Real Exchange Rates and Real Interest Rate Differentials. Have We Misse:d the Business-Cycle Relationship?", Journal of Monetary Economics, 33 (February) 537.

Beveridge, S., and Charles R. Nelson, 1981. "A New Approach to the Decomposition of Economic Time Series into Permanent and Transitory Components, with Particular Attnetion to the Measurement of the 'Business Cycle'," Journal of Monetary Economics 7 (April) 151-174.

Blanchard, Olivier J., and Danny Quah, 1989. "The Dynamic Effects of Aggregate Demand and Supply Disturbances," American Economic Review 79 (December) 655-73.

1993. "The Dynamic Effects of Aggregate Demand and Supply Disturbances: Reply," American Economic Review 83 (June) 653-58.

Cagan, Phillip, 1956. "The Monetary Dynamics of Hyperinflation," in Milton Friedman, ed., Studies in the: Quantity Theory of Money, Chicago: University of Chicago Press.

Campbell, John Y., and Richard Clarida, 1987. "The Dollar and Real Interest Rates: An Empirical Investigation," Carnegie-Rochester Conference Series on Public Policy, 27, pp. 103-140.

Cheung, Yin-Wong, and Kon S. Lai, 1993. "Finite Sample Sizes of Johansen's Likelihood Ratio Tests for Cointegration," Oxford Bulletin of Economics and Statistics 313-328.

Clarida, Richard, and Jordi Gali, 1994. "Sources of Real Exchange Rate Fluctuations: How Important are Nominal Shocks?", Carnegie-Rochester Conference Series on Public Policy, forthcoming.

Delgado, Francisco A., 1991. "Hysteresis, Menu Costs, and Pricing with Random Exchange Rates," Journal of Monetary Economics 28 (December) 461-484.

Dickey, D.A. and W.A. Fuller, 1979. "Distribution of the Estimators for Autoregressive Time Series with a Unit Root," Journal of the American Statistical Association 74, 427-431.

Dornbusch, Rudiger, 1976. "Expectations and Exchange Rate Dynamics, "Journal of Political Economy 84 (December) 1161-1176. 
Edison, Hali J., and Dianne Pauls, 1993. "A Re-Assessment of the Relationship Between Real Exchange Rates and Real Interest Rate: 1974-1990," Journal of Monetary Economics 31 (April) 149-164.

Engel, Charles, 1993. "Is Real Exchange Rate Variability Caused by Relative Price Changes? An Empirical Investigation," Journal of Monetary Economics 32 (August) 35-50.

Engel, Charles, and John H. Rogers, 1994. "How Wide is the Border?", NBER working paper 4829.

Engle, Robert F., and C.W.J. Granger, 1987. "Co-integration and Error Correction: Representation, Estimation, and Testing," Econometrica 55 (March) 251-276.

Faust, Jon and Eric M. Leeper, 1994. "When Do Long-run Identifying Restrictions Give Reliable Results," mimeo, Board of Governors of the Federal Reserve, (February).

Frenkel, Jacob, 1978. "Purchasing Power Parity: Doctrinal Perspectives and Evidence fron the 1920's," Journal of International Economics (May) 169-191.

Huizinga, John, 1987. "An Empirical Investigation of the Long-Run Behavior of Real Exchange Rates," Carnegie-Rochester Conference Series on Public Policy, 27 (Autumn) 149-2114.

Johansen, Soren, 1991. "Estimation and Hypothesis Testing of Cointegration Vectors in Gaussian Vector Autoregressive Models," Econometrica 159, 1551-80.

King, Robert G. and Mark Watson, 1992. "Testing Long Run Neutrality," mimeo, University of Rochester, (July).

Krugman, Paul R., 1978. "Purchasing Power Parity and Exchange Rates: Another Look at the Evidence," Journal of International Economics (August) 397-407.

Lastrapes, William D., 1992. "Sources of Fluctuations in Real and Nominal Exchange Rates," Review of Economics and Statistics 74 (August) 530-539.

Lippi, Marco and Lucrezia Reichlin, 1993. "The Dynamic Effects of Aggregate Demand arid Supply Disturbances: Comment," American Economic Review 83 (June) 644-52.

Mark, Nelson C. 1990. "Real and Nominal Exchange Rates in the Long Run: An Empirical Investigation," Journal of International Economics 28 (February) 115-136.

McNown, Robert, and Myles Wallace, 1989. "National Price Levels, Purchasing Power Parity, and Cointegration: A Test of Four High Inflation Economies," Journal of International Money and Finance 8, 533-555.

Mussa, M. 1982. "A Model of Exchange Rate Dynamics," Journal of Political Economy, 90, 74-104.

Mussa, M. 1986. "Nominal Exchange Rate Regimes and the Behavior of Real Exchange Rátes: Evidence and Implications," in K. Brunner and A. Meltzer, (eds.) Carnegie Rochester Conference Series on Public Policy, 25, 117-214. 
Osterwald-Lenum, Michael, 1992. "A Note with Quantiles of the Asymptotic Distribution of the Maximum Likelihood Cointegration Rank Test Statistics," Oxford Bulletin of Economics and Statistics 54, pp. 461-471.

Rogers, John H., and Michael A. Jenkins, 1994. "Haircuts or Hysteresis? Sources of Movements in Real Exchange Rates," Journal of International Economics, forthcoming.

Rogers, John H., and Ping Wang, 1993. "Sources of Fluctuations in Relative Prices: Evidence From High Inflation Countries," Review of Economics and Statistics (November) 589-605.

Stock, James H., 1991. "Confidence Intervals for the Largest Autoregressive Root in U.S. Macroeconomic Time Series," Journal of Monetary Economics 28 (December) 435-459.

Stockman, Alan C., 1980. "A Theory of Exchange Rate Determination," Journal of Political Economy 88 (August) 673-698.

Stockman, Alan C., 1983. "Real Exchange Rates Under Alternative Exchange Rate Regimes," Journal of International Money and Finance 2, 147-166.

Stockman, Alan C., 1988. "Real Exchange Rate Variability Under Pegged and Floating Nominal Exchange Rate Systems: An Equilibrium Theory," in K. Brunner and A. Meltzer, (eds.) Carnctgie Rochester Conference Series on Public Policy 29, 259-294.

Stockman, A an C., and Alejandro Hernandez, 1988. "Exchange Controls, Capital Controls, and International Financial Markets," American Economic Review 78 (June) 362-374.

Stockman, Alan C., and Lee E. Ohanian, 1993. "Short-Run Independence of Monetary Policy under Pegged Exchange Rates and Effects of Money on Exchange Rates and Interest Rates," working paper, University of Rochester.

Taylor, Mark P., and Patrick C. McMahon, 1988. "Long Run Purchasing Power Parity in the 1920 s," European Economic Review 32, 179-197. 


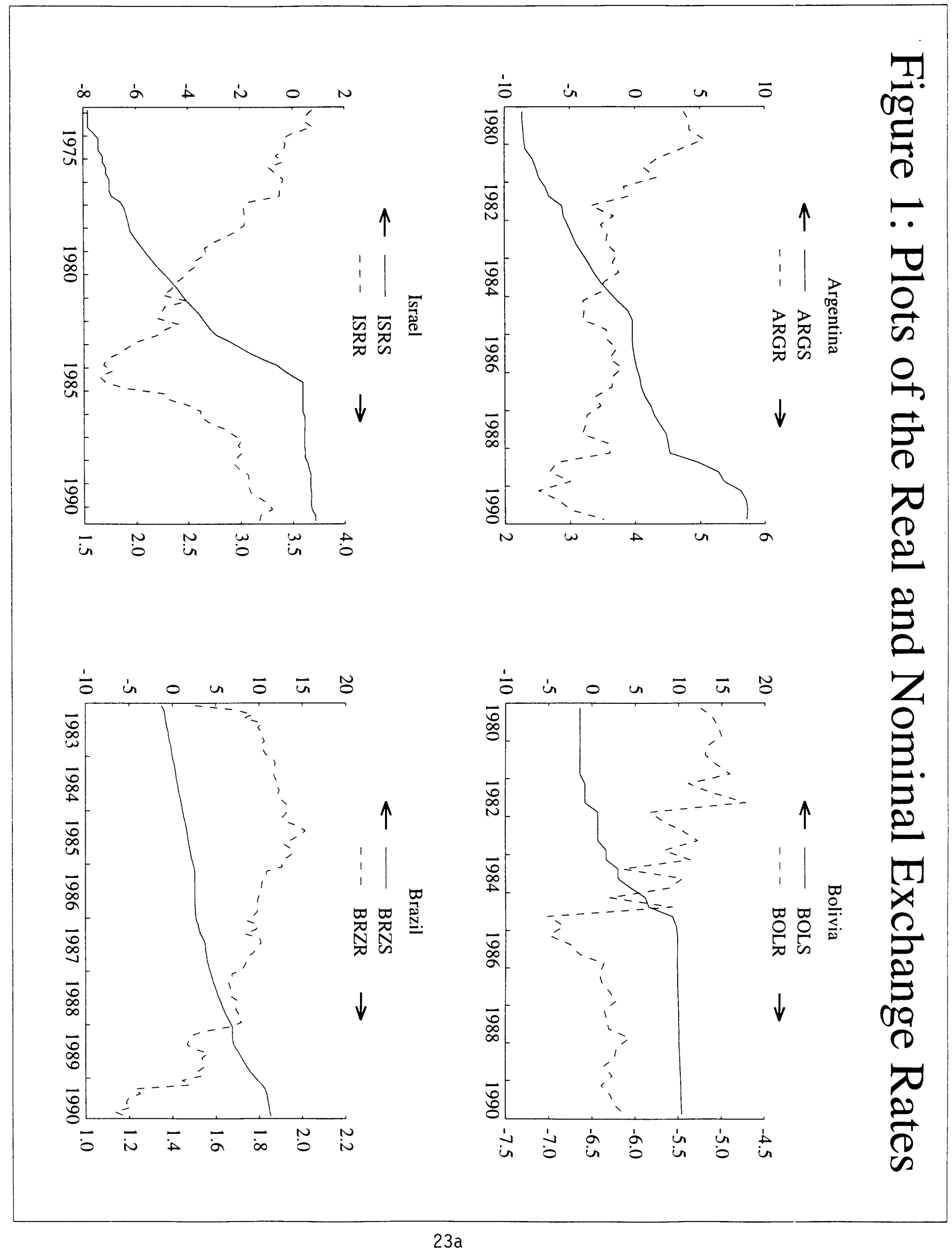


Figure 2a; Impulse Response Functions (Argentina)

Response of Real Exchange Rate (First-Difference and Log-Levels) to

(1) Government Size, (2) Output, (3) Money Growth Shocks
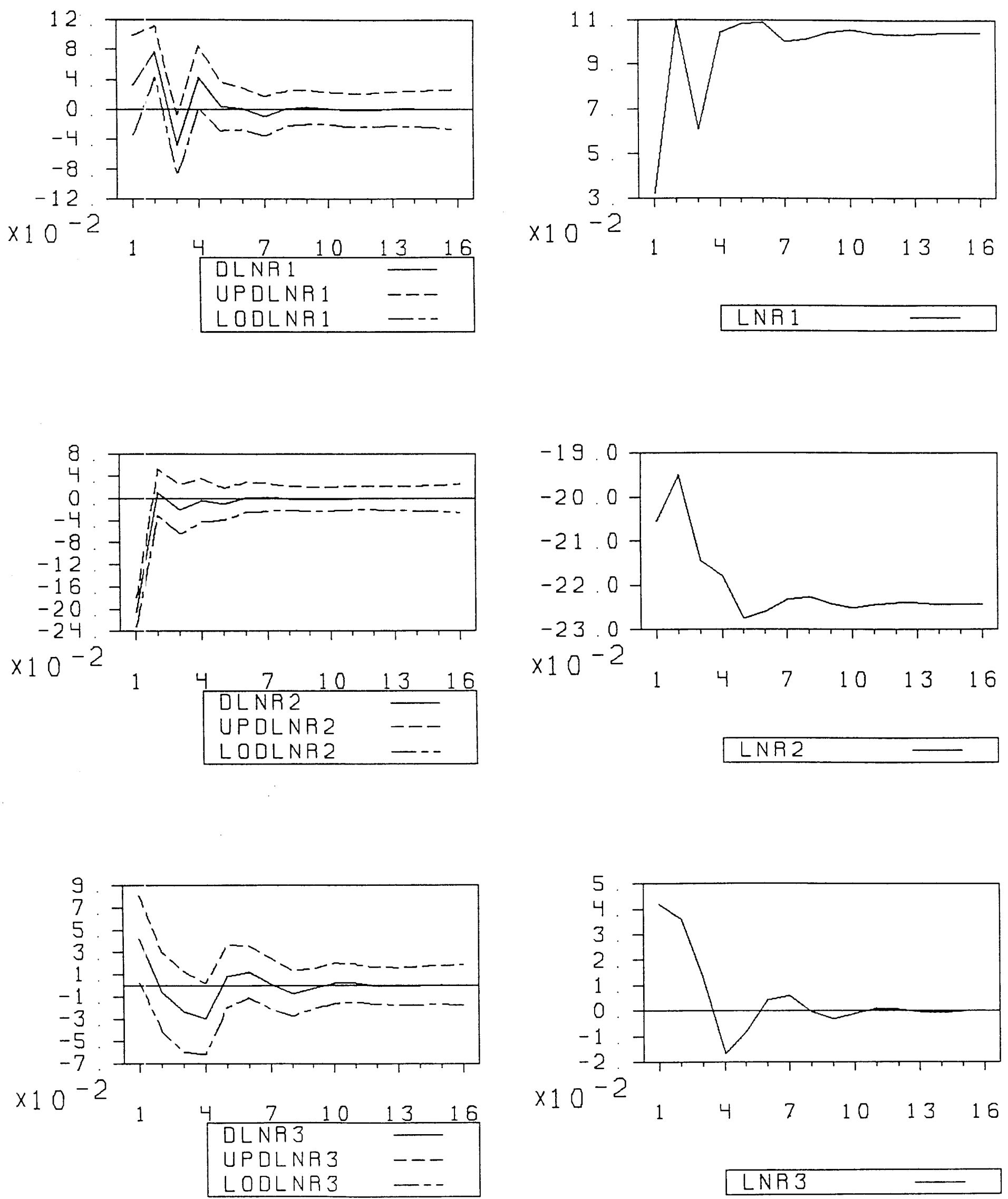

*The solid line is the point estimate and dashed lines are plus- and minus- one standard deviation. 
Figure 2b; Impulse Response Functions (Bolivia)

Response of Real Exchange Rate (First-Difference and Log-Levels) to

(1) Government Size, (2) Output, (3) Money Growth Shocks
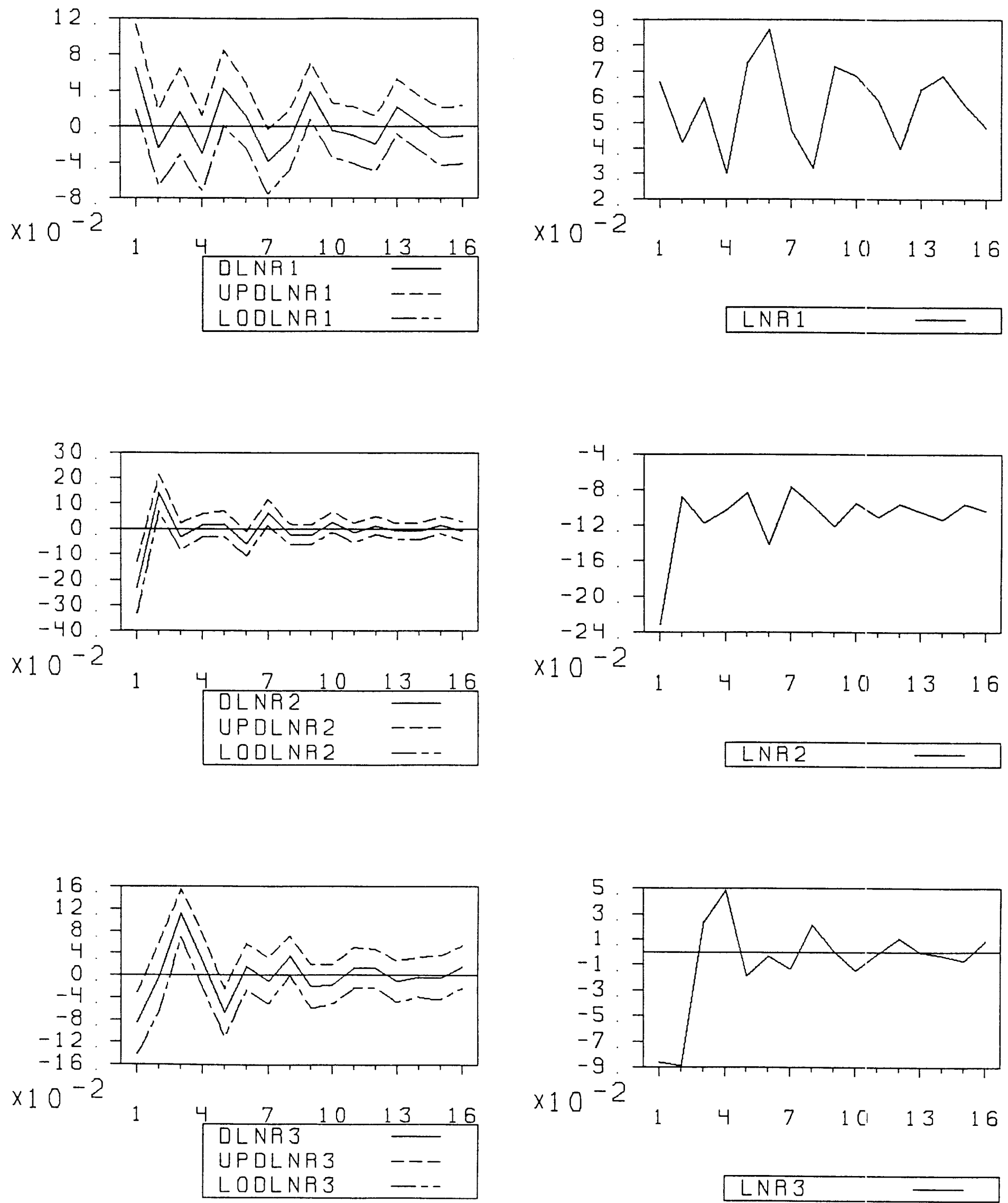

*The solid line is the point estimate and dashed lines are plus- and minus- one standard deviation. 
Figure 2c; Impulse Response Functions (Brazil)

Response of Real Exchange Rate (First-Difference and Log-Levels) to

(1) Government Size, (2) Output, (3) Money Growth Shocks

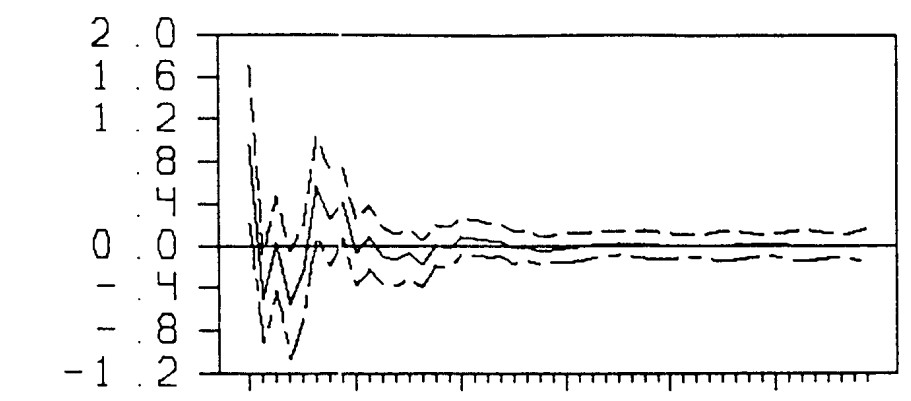

$\times 10-2$
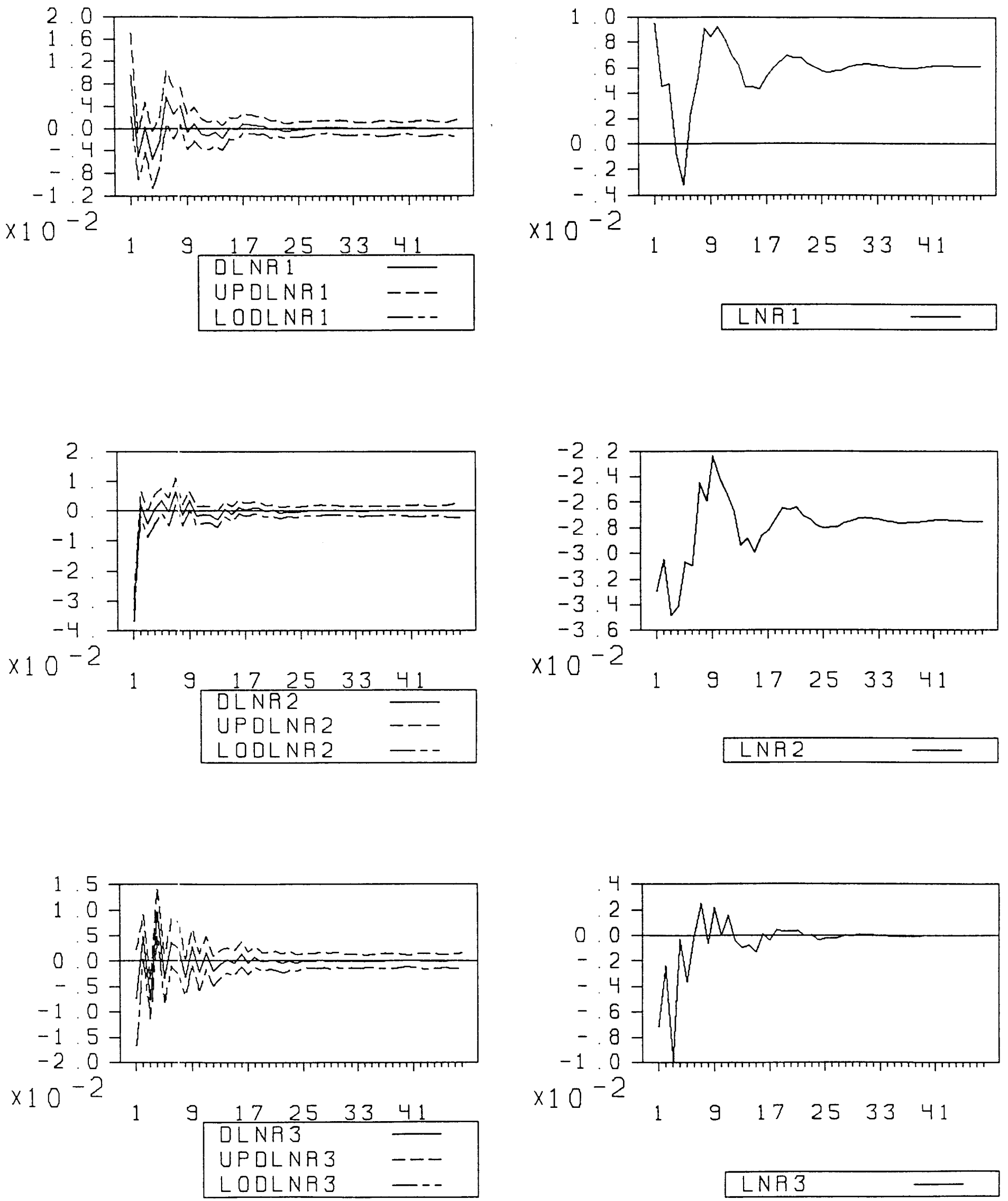

*The solid line is the point estimate and dashed lines are plus- and minus- one standard deviation. 
Figure 2d; Impulse Response Functions (Israel)

Response of Real Exchange Rate (First-Difference and Log-Levels) to

(1) Government Size, (2) Output, (3) Money Growth Shocks
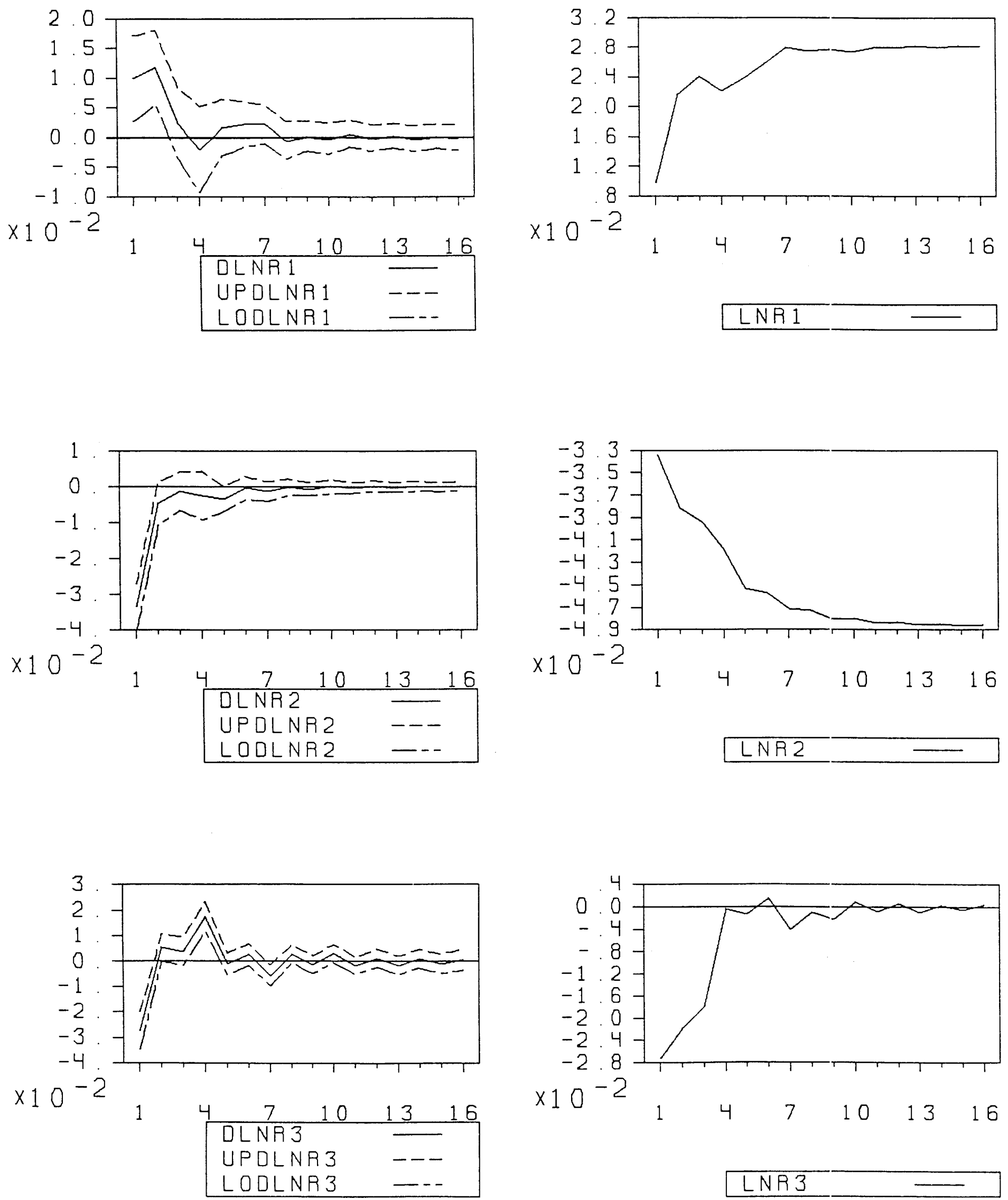

*The solid line is the point estimate and dashed lines are plus- and minus- one standard deviation. 
Figure 3; Impulse Response Functions (Israel)

Response of Real Exchange Rate (First-Difference and Log-Levels) to

(1) Government Size, (2) Supply, (3) Demand, (4) Money Growth Shocks
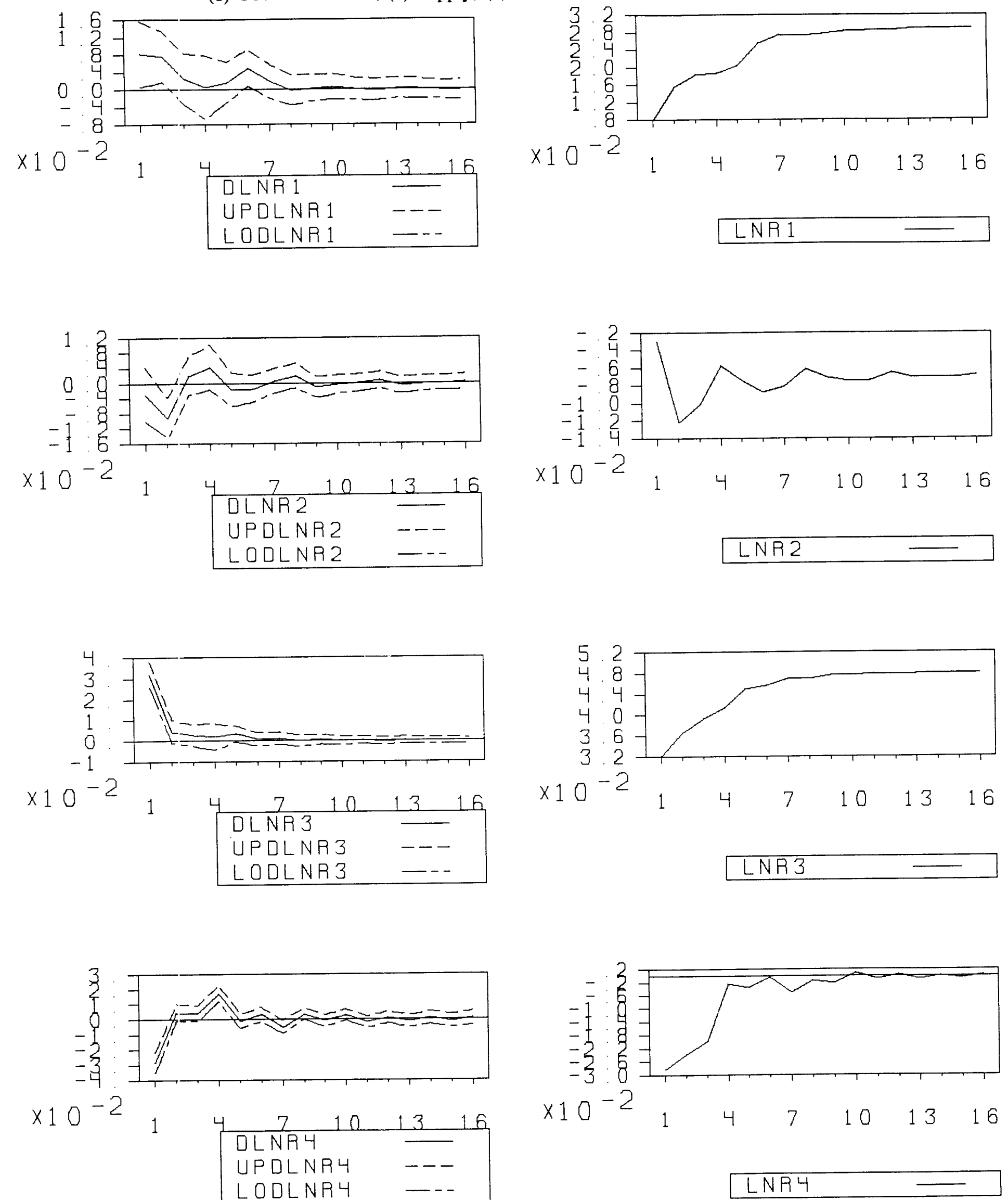

"The solid line is the point estimate and dashed lines are plus- and minus- one standard deviation. 
Figure 4; Impulse Response Functions (Israel)

Response of the Real Exchange Rate (First-Difference and Log-Levels) to

Shocks to (1) Government Size, (2) Output, (3) Money, (4) Exchange Rate
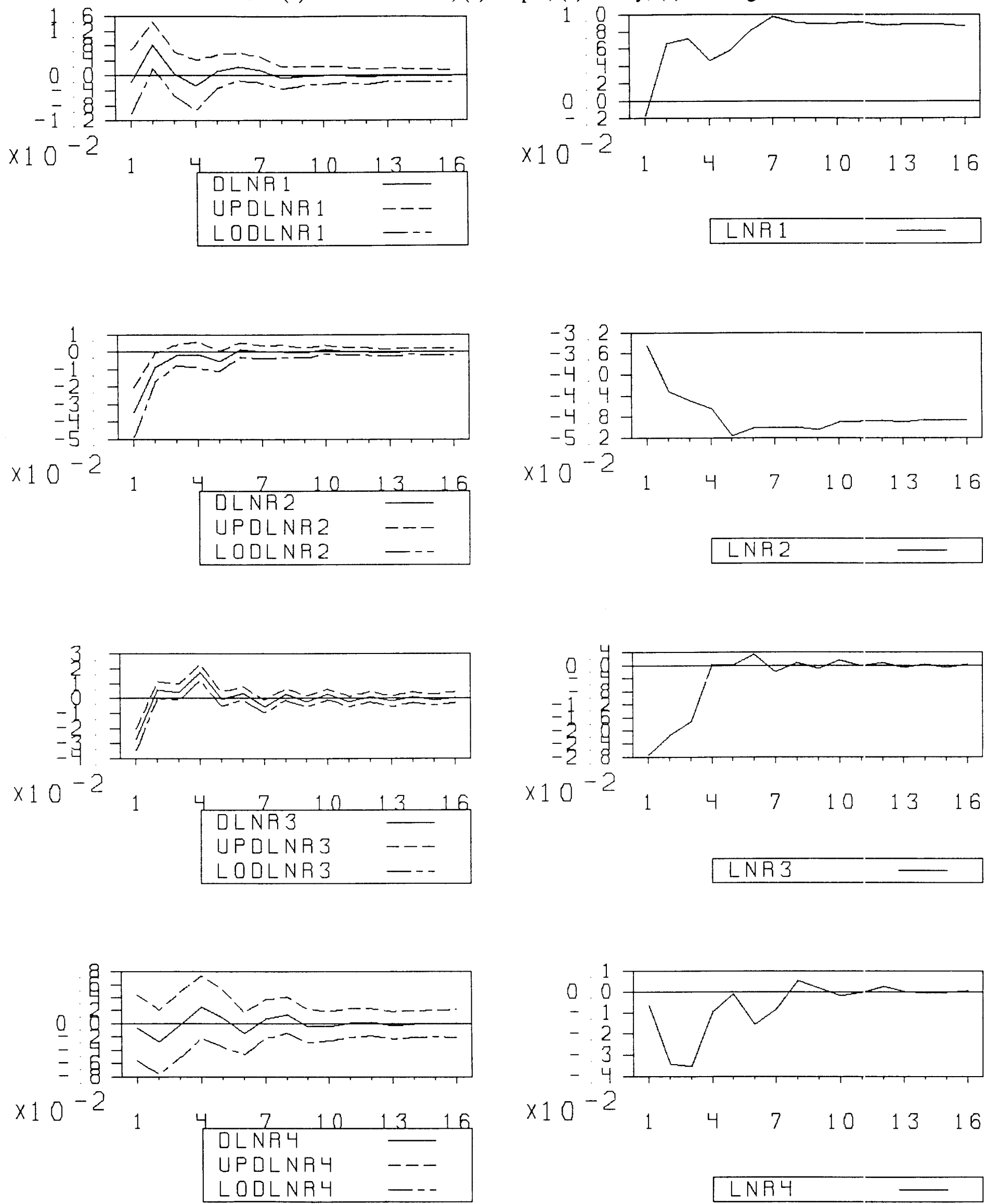

"The solid line is the point estimate and the dashed lines are plus- and minus- one standard deviation. 
Table 1; Unit Roots Tests

\begin{tabular}{|c|c|c|c|c|c|c|}
\hline $\begin{array}{c}\text { Variable } \\
\text { [ARG] }\end{array}$ & $\mathrm{ADF}_{\tau}$ & $\begin{array}{c}95 \% \text { C.I. } \\
{\left[\mathrm{ADF}_{\tau}\right]}\end{array}$ & $\begin{array}{c}\text { lag } \\
\text { length }\end{array}$ & $\mathrm{ADF}_{\mu}$ & $\begin{array}{c}95 \% \text { C.I. } \\
{\left[\mathrm{ADF}_{\mu}\right]}\end{array}$ & $\begin{array}{c}\text { lag } \\
\text { length }\end{array}$ \\
\hline$(g / y)$ & $-2.40^{\tau}$ & $\begin{array}{ll}.60 & 1.09 \\
\end{array}$ & 2 & -1.29 & $\begin{array}{ll}.82 & 1.06 \\
\end{array}$ & 2 \\
\hline $\ln (\mathrm{m})$ & $-3.58^{*_{\tau}}$ & $.18 \quad 1.04$ & 4 & $-3.18^{*}$ & $.30 \quad .96$ & 4 \\
\hline $\ln (y)$ & $-4.14^{* *}$ & $--\quad .80$ & 4 & $-4.39^{* *}$ & $--\quad .61$ & 4 \\
\hline $\ln (\mathrm{R})$ & -1.77 & $.76 \quad 1.11$ & 2 & -2.56 & $.50 \quad 1.04$ & 2 \\
\hline $\ln (s)$ & $-3.11^{\tau}$ & $.37 \quad 1.07$ & 3 & -0.13 & $.98 \quad 1.11$ & 3 \\
\hline$D(g / y)$ & $-4.38^{* *}$ & $\begin{array}{l}--.70 \\
\end{array}$ & 4 & $-4.42^{* *}$ & $--\quad .61$ & 2 \\
\hline $\mathrm{D} \ln (\mathrm{m})$ & -3.39 & $.26 \quad 1.05$ & 4 & $-3.12^{*}$ & $.33 \quad 1.00$ & 4 \\
\hline $\mathrm{D} \ln (\mathrm{R})$ & -3.42 & $.26 \quad 1.05$ & 2 & $-3.01^{*}$ & $\begin{array}{ll}.37 & 1.02 \\
\end{array}$ & 2 \\
\hline $\mathrm{D} \ln (\mathrm{s})$ & -2.87 & $.44 \quad 1.08$ & 3 & $-2.97^{*}$ & $\begin{array}{ll}.37 & 1.02 \\
\end{array}$ & 3 \\
\hline $\mathrm{D} 2 \ln (\mathrm{s})$ & $-3.55^{*}$ & $.20 \quad 1.04$ & 3 & $-3.54^{*}$ & $.19 \quad .87$ & 3 \\
\hline
\end{tabular}

\begin{tabular}{|c|c|c|c|c|c|c|}
\hline $\begin{array}{c}\text { Variable } \\
\text { [BOL] }\end{array}$ & $\mathrm{ADF}_{\tau}$ & $\begin{array}{c}95 \% \text { C.I. } \\
{\left[\mathrm{ADF}_{\tau}\right]}\end{array}$ & $\begin{array}{c}\text { lag } \\
\text { length }\end{array}$ & $\mathrm{ADF}_{\mu}$ & $\begin{array}{c}95 \% \text { C.I. } \\
{\left[\mathrm{ADF}_{\mu}\right]}\end{array}$ & $\begin{array}{c}\text { lag } \\
\text { length }\end{array}$ \\
\hline$(g / y)$ & -2.85 & $\begin{array}{rr}.41 & 1.09 \\
\end{array}$ & 3 & -2.43 & $.50 \quad 1.06$ & 3 \\
\hline $\ln (m)$ & -1.42 & $.84 \quad 1.12$ & 3 & -1.58 & $.75 \quad 1.10$ & 3 \\
\hline $\ln (y)$ & $-0.29^{\tau}$ & $1.04 \quad 1.12$ & 3 & -1.12 & $.86 \quad 1.10$ & 3 \\
\hline $\ln (\mathrm{R})$ & $-2.72^{\tau}$ & $.46 \quad 1.09$ & 3 & -1.46 & $\begin{array}{ll}.78 \quad 1.10 \\
\end{array}$ & 3 \\
\hline $\ln (\mathrm{s})$ & -1.88 & $.72 \quad 1.12$ & 3 & -1.62 & $.74 \quad 1.10$ & 3 \\
\hline $\mathrm{D}(\mathrm{g} / \mathrm{y})$ & $-5.14^{* *}$ & $--\quad .38$ & 3 & $-5.21^{* *}$ & $--\quad .28$ & 3 \\
\hline $\mathrm{D} \ln (\mathrm{m})$ & $-3.52^{*}$ & $.14 \quad 1.05$ & 3 & $-3.42^{*}$ & $.15 \quad .88$ & 3 \\
\hline$D \ln (y)$ & $-5.84^{* *}$ & --.18 & 3 & $-4.92^{* *}$ & $\begin{array}{ll}-- & .45 \\
\end{array}$ & 3 \\
\hline $\mathrm{Dln}(\mathrm{R})$ & $-4.30^{* *}$ & $--\quad .71$ & 3 & $-4.37^{* *}$ & $--\quad .59$ & 3 \\
\hline $\mathrm{D} \ln (\mathrm{s})$ & -2.19 & $\begin{array}{ll}63 & 1.11 \\
\end{array}$ & 3 & -2.04 & $\begin{array}{ll}.62 & 1.08\end{array}$ & 3 \\
\hline $\mathrm{D} 2 \ln (\mathrm{s})$ & $-3.68^{*}$ & $.06 \quad 1.04$ & 3 & $-3.67^{* *}$ & $--\quad .80$ & 3 \\
\hline
\end{tabular}


Table 1, cont'd; Unit Roots Tests

\begin{tabular}{|c|c|c|c|c|c|c|c|}
\hline $\begin{array}{c}\text { Variable } \\
\text { [BRZ] }\end{array}$ & $\mathrm{ADF}_{\tau}$ & $\begin{array}{r}95 \% \\
\text { [AD }\end{array}$ & $\begin{array}{l}\text { C.I. } \\
\left.\mathrm{F}_{\tau}\right]\end{array}$ & $\begin{array}{l}\text { lag } \\
\text { length }\end{array}$ & $\mathrm{ADF}_{\mu}$ & $\begin{array}{c}95 \% \text { C.I. } \\
{\left[\mathrm{ADF}_{\mu}\right]}\end{array}$ & $\begin{array}{c}\text { lag } \\
\text { length }\end{array}$ \\
\hline$(g / y)$ & $-4.22^{* *_{\tau}}$ & -- & .88 & 6 & $-3.02^{*}$ & $.67 \quad 1.01$ & 4 \\
\hline $\ln (m)$ & -2.82 & .73 & 1.04 & 6 & -2.40 & $.77 \quad 1.03$ & 6 \\
\hline $\ln (y)$ & -2.53 & .79 & 1.04 & 6 & -2.37 & $\begin{array}{ll}.78 & 1.03 \\
\end{array}$ & 6 \\
\hline $\ln (\mathrm{R})$ & $-0.87^{\tau}$ & .97 & 1.06 & 8 & -1.93 & $.84 \quad 1.04$ & 8 \\
\hline $\ln (s)$ & 0.13 & 1.02 & 1.07 & 4 & 2.17 & -- $\quad--$ & 4 \\
\hline $\operatorname{Dln}(\mathrm{m})$ & $-3.69^{*}$ & .55 & 1.02 & 8 & $-3.67^{* *}$ & --.90 & 8 \\
\hline $\operatorname{Dln}(y)$ & $-7.19^{* *}$ & -- & -- & 6 & $-7.09^{* *}$ & -- & 6 \\
\hline $\mathrm{D} \ln (\mathrm{R})$ & $-4.64^{* *_{\tau}}$ & & .81 & 8 & $-2.98^{*}$ & $.67 \quad 1.01$ & 8 \\
\hline $\operatorname{Dln}(s)$ & $-3.49^{* \tau}$ & .59 & 1.02 & 8 & -2.42 & $.77 \quad 1.03$ & 8 \\
\hline
\end{tabular}

\begin{tabular}{|c|c|c|c|c|c|c|}
\hline $\begin{array}{l}\text { Variable } \\
\text { [ISR] }\end{array}$ & $\mathrm{ADF}_{\tau}$ & $\begin{array}{c}95 \% \text { C.I. } \\
{\left[\mathrm{ADF}_{\tau}\right]}\end{array}$ & $\begin{array}{c}\text { lag } \\
\text { length }\end{array}$ & $\mathrm{ADF}_{\mu}$ & $\begin{array}{c}95 \% \text { C.I. } \\
{\left[\mathrm{ADF}_{\mu}\right]}\end{array}$ & $\begin{array}{r}\text { lag } \\
\text { length }\end{array}$ \\
\hline$(g / y)$ & -2.79 & $.68 \quad 1.05$ & 4 & -2.82 & $.65 \quad 1.02$ & 4 \\
\hline $\ln (m)$ & -1.25 & $\begin{array}{ll}93 & 1.07\end{array}$ & 4 & -1.58 & $.85 \quad 1.06$ & 4 \\
\hline $\ln (y)$ & $-3.47^{*_{\tau}}$ & $.83 \quad 1.01$ & 3 & -0.41 & $.99 \quad 1.02$ & 3 \\
\hline $\ln (\mathrm{R})$ & -1.66 & $.87 \quad 1.07$ & 4 & -1.97 & $.79 \quad 1.05$ & 4 \\
\hline $\ln (s)$ & $-2.19^{\tau}$ & $.79 \quad 1.06$ & 3 & -1.02 & $.92 \quad 1.06$ & 3 \\
\hline$D(g / y)$ & $-3.99^{*}$ & $--\quad .90$ & 4 & $-4.02^{* *}$ & $--\quad .83$ & 4 \\
\hline $\operatorname{Dln}(\mathrm{m})$ & $-4.10^{* *}$ & $--\quad .88$ & 2 & $-3.55^{* *}$ & $.48 \quad .91$ & 2 \\
\hline $\operatorname{Dln}(y)$ & $-6.28^{* *}$ & $--\quad--$ & 3 & $-6.33^{* *}$ & $--\quad--$ & 3 \\
\hline $\mathrm{D} \ln (\mathrm{R})$ & $-4.42^{* *}$ & -- .81 & 4 & $-4.11^{* *}$ & $--\quad .81$ & 4 \\
\hline $\operatorname{Dln}(s)$ & -2.26 & $\begin{array}{ll}.77 \quad 1.06 \\
\end{array}$ & 4 & -2.25 & $.75 \quad 1.04$ & 4 \\
\hline $\mathrm{D} 2 \ln (\mathrm{s})$ & $-4.35^{* *}$ & $\begin{array}{l}-. \\
-\quad .82 \\
\end{array}$ & 4 & $-4.32^{* *}$ & $--\quad .78$ & 4 \\
\hline
\end{tabular}

Notes: $\mathrm{ADF}_{\tau}\left(\mathrm{ADF}_{\mu}\right)$ denotes the Augmented Dickey-Fuller (1979) test statistic for the unit root null hypothesis; a **, * indicates rejection of the unit root null in favor of the trend-stationary (stationary with non-zero drift) alternative at $1 \%$ and $5 \%$ respectively. 95\% C.I. denotes the $95 \%$ confidence interval for the largest autoregressive root, which are constructed from the ADF statistics using Stock's (1991) procedure. A " -- " indicates the calculation is not available from Stock's tables. Lag length gives the number of lagged first-differences used in the ADF test. Where quarterly data are used (Argentina, Bolivia, and Israel), results are estimated for lag lengths of 2, 3, and 4, and where monthly data are used (Brazil), results are estimated for lag lengths of 4,6 , and 8 . A superscript " $\tau$ " indicates that there is a significant time trend in the variable. 
Table 2; Johansen's Trace Test for Cointegration

\begin{tabular}{||l|c|c|c|c|c|c||}
\hline Country & System & $\mathrm{p}=0$ & $\mathrm{p} \leq 1$ & $\mathrm{p} \leq 2$ & $\mathrm{p} \leq 3$ & Lags \\
\hline Argentina & $(\mathrm{g} / \mathrm{y}), \ln (\mathrm{R}), \ln (\mathrm{m})$ & 22.8 & 8.76 & 0.08 & - & 4 \\
\hline & $(\mathrm{g} / \mathrm{y}), \ln (\mathrm{R}), \ln (\mathrm{m}), \Delta \ln (\mathrm{s})$ & 39.4 & 14.3 & 3.86 & 0.06 & 4 \\
\hline Bolivia & $(\mathrm{g} / \mathrm{y}), \ln (\mathrm{R}), \ln (\mathrm{m})$ & 17.4 & 8.40 & 3.17 & - & 4 \\
\hline & $(\mathrm{g} / \mathrm{y}), \ln (\mathrm{R}), \ln (\mathrm{m}), \Delta \ln (\mathrm{s})$ & $56.1^{*}$ & 17.0 & 7.81 & 3.68 & 4 \\
\hline & $(\mathrm{g} / \mathrm{y}), \ln (\mathrm{R}), \ln (\mathrm{m}), \Delta \ln (\mathrm{s})$ & 38.4 & 18.0 & 5.75 & 2.01 & 3 \\
\hline & $(\mathrm{g} / \mathrm{y}), \ln (\mathrm{y}), \ln (\mathrm{R}), \ln (\mathrm{m})$ & 31.9 & 16.8 & 8.57 & 2.59 & 4 \\
\hline Israel & $(\mathrm{g} / \mathrm{y}), \ln (\mathrm{R}), \ln (\mathrm{m})$ & 27.1 & 9.59 & 1.95 & - & 4 \\
\hline & $(\mathrm{g} / \mathrm{y}), \ln (\mathrm{R}), \ln (\mathrm{m}), \Delta \ln (\mathrm{s})$ & 36.2 & 17.9 & 8.21 & 1.82 & 4 \\
\hline & $(\mathrm{g} / \mathrm{y}), \ln (\mathrm{y}), \ln (\mathrm{R}), \ln (\mathrm{m})$ & 31.0 & 11.9 & 4.18 & 0.14 & 4 \\
\hline
\end{tabular}

Notes: We denote significant at $5 \%$ by $*$. In Johansen's trace test, the null is that there are no more than $\mathrm{p}$ cointegrating vectors in the system (or n-p distinct unit roots). Reported statistics are calculated using the Cheung and Lai (1993) correction. Critical values for (n-4) equal to 1,2,3,4 are $3.76,15.5,29.7,47.2(95 \%)$. These are taken from Table 1 of Osterwald-Lenum (1992). 
Table 3; Results from the Benchmark Model

Coefficients of the Long-Run Moving Average Matrix and Variance Decomposition of $\Delta \ln (R)$

\begin{tabular}{|c|c|c|c|c|}
\hline Coeff: & ARG & BOL & $\mathrm{BRZ}$ & ISR \\
\hline $\mathrm{C}_{11}(+)$ & $0.83(1.70)$ & $0.39(0.10)$ & $0.78(0.46)$ & $0.56(0.13)$ \\
\hline $\mathrm{C}_{21}(+)$ & $2.09(16.5)$ & $0.78(0.48)$ & $0.12(0.66)$ & $3.50(2.78)$ \\
\hline $\mathrm{C}_{22}(-)$ & $-1.28(0.74)$ & $-0.27(0.21)$ & $-0.66(0.21)$ & $-0.67(0.23)$ \\
\hline $\mathrm{C}_{31}(-)$ & $-1.80(13.6)$ & $-1.23(0.88)$ & $-0.50(8.15)$ & $-10.8(10.3)$ \\
\hline $\mathrm{C}_{32}(+)$ & $1.01(0.49)$ & $0.21(0.15)$ & $3.29(1.50)$ & $1.77(0.60)$ \\
\hline $\mathrm{C}_{33}(-)$ & $-0.59(0.11)$ & $-0.75(0.19)$ & $-1.07(0.35)$ & $-0.79(0.22)$ \\
\hline \multicolumn{5}{|c|}{ VDC $\Delta \ln (\mathbf{R})$} \\
\hline \multirow[t]{2}{*}{$\varepsilon^{g}$} & $2.32 / 13.7 / 19.7$ & $6.67 / 5.68 / 10.0$ & $7.44 / 11.9 / 12.8$ & $4.99 / 11.0 / 10.0$ \\
\hline & $(15.8 / 14.2 / 13.7)$ & $(10.1 / 9.42 / 9.94)$ & $(11.8 / 9.58 / 9.21)$ & $(7.31 / 8.97 / 8.77)$ \\
\hline \multirow[t]{2}{*}{$\varepsilon^{y}$} & $93.8 / 82.8 / 74.2$ & $82.0 / 85.7 / 67.7$ & $88.4 / 72.1 / 70.2$ & $57.1 / 53.0 / 44.9$ \\
\hline & $(17.5 / 15.6 / 14.3)$ & $(15.8 / 14.7 / 13.4)$ & $(17.5 / 14.0 / 13.1)$ & $(18.9 / 17.4 / 15.3)$ \\
\hline \multirow[t]{2}{*}{$\varepsilon^{\mu}$} & $3.88 / 3.47 / 6.06$ & $11.4 / 8.59 / 22.3$ & $4.18 / 16.0 / 16.9$ & $37.9 / 36.0 / 45.0$ \\
\hline & $(8.65 / 8.05 / 9.96)$ & $(13.7 / 12.1 / 10.9)$ & $(12.8 / 11.4 / 11.3)$ & $(18.2 / 15.7 / 14.6)$ \\
\hline
\end{tabular}

Notes: The $C_{i j}$ elements represent the long-run effect of the fiscal shock, $\varepsilon^{g}$, on government size: $\left(C_{11}\right)$, the real exchange rate $\left(C_{21}\right)$, and real money balances $\left(C_{31}\right)$, the long-run effect of the output shock, $\varepsilon^{y}$, cn the real exchange rate $\left(\mathrm{C}_{22}\right)$ and real money balances $\left(\mathrm{C}_{32}\right)$, and the long-run effect of the money growth shock, $\varepsilon^{\mu}$, on real money balances $\left(C_{33}\right)$. In parenthesis is the coefficient's predicted sign. The reported variance decompostion (VDC) results indicate the percentage of the forecast error variance of $\Delta \ln (R)$ that is due to each shock at the 1st horizon, half-year horizon, and 4-year horizon. Standard errors obtained from Monte Carlo simulations with 1000 draws are in parenthesis. 
Table 4; Results from the 4-by-4 Model with Output (Alternative-1)

Coefficients of the Long-Run Moving Average Matrix and Variance Decomposition of $\Delta \ln (R)$

\begin{tabular}{|c|c|c|c|c|}
\hline Coeff: & ARG & BOL & $\mathrm{BRZ}$ & ISR \\
\hline$C_{11}(+)$ & $0.83(2.46)$ & $0.40(0.17)$ & $0.85(2.29)$ & $0.69(0.24)$ \\
\hline $\mathrm{C}_{2 \mathrm{I}}(?)$ & $-0.80(6.25)$ & $-0.07(0.84)$ & $-0.33(0.54)$ & $0.69(0.61)$ \\
\hline $\mathrm{C}_{22}(+)$ & $1.63(1.30)$ & $0.38(0.23)$ & $0.60(0.13)$ & $0.44(0.07)$ \\
\hline $\mathrm{C}_{31}(-)$ & $1.92(7.66)$ & $1.43(1.36)$ & $0.16(0.56)$ & $4.08(3.74)$ \\
\hline $\mathrm{C}_{32}(-)$ & $-2.72(2.66)$ & $-0.48(0.27)$ & $.005(0.20)$ & $-0.27(0.58)$ \\
\hline $\mathrm{C}_{33}(+)$ & $1.05(0.41)$ & $0.30(0.30)$ & $0.56(0.20)$ & $0.67(0.21)$ \\
\hline $\mathrm{C}_{41}(-)$ & $-0.94(7.20)$ & $-1.91(1.58)$ & $-0.51(4.85)$ & $-13.6(13.6)$ \\
\hline $\mathrm{C}_{42}(+)$ & $0.92(2.59)$ & $2.04(0.42)$ & $0.70(1.77)$ & $0.57(2.07)$ \\
\hline $\mathrm{C}_{43}(-)$ & $-0.89(0.35)$ & $-0.05(0.20)$ & $-2.96(1.26)$ & $-1.76(0.55)$ \\
\hline $\mathrm{C}_{44}(-)$ & $-0.69(0.13)$ & $-1.55(0.11)$ & $-1.10(0.31)$ & $-0.82(0.22)$ \\
\hline \multicolumn{5}{|c|}{$\mathrm{VDC} \Delta \ln (\mathrm{R})$} \\
\hline \multirow[t]{2}{*}{$\varepsilon^{8}$} & $2.86 / 14.9 / 20.3$ & $18.1 / 11.9 / 14.9$ & $4.25 / 7.76 / 9.87$ & $3.48 / 5.94 / 6.34$ \\
\hline & $-(14.6 / 13.4 / 13.1)$ & $(4.60 / 8.89 / 11.1)$ & $(10.1 / 8.67 / 8.95)$ & $(6.56 / 7.37 / 7.96)$ \\
\hline \multirow[t]{2}{*}{$\varepsilon^{y}$} & $30.0 / 25.7 / 23.2$ & $.002 / 4.42 / 15.2$ & $3.02 / 6.63 / 10.8$ & $0.47 / 4.41 / 4.90$ \\
\hline & $-(20.6 / 17.1 / 12.0)$ & $(17.7 / 19.6 / 12.4)$ & $(7.76 / 6.79 / 7.81)$ & $(4.11 / 5.64 / 5.48)$ \\
\hline \multirow[t]{2}{*}{$\varepsilon^{\mathrm{d}}$} & $58.0 / 49.6 / 46.3$ & $80.5 / 74.9 / 49.8$ & $82.2 / 66.2 / 59.4$ & $54.2 / 50.5 / 42.0$ \\
\hline & $(22.3 / 18.6 / 13.7)$ & $(17.3 / 19.2 / 13.8)$ & $(19.6 / 14.9 / 14.2)$ & $(18.1 / 16.8 / 13.8)$ \\
\hline \multirow[t]{2}{*}{$\varepsilon^{\mu}$} & $9.17 / 10.1 / 10.2$ & $1.39 / 8.82 / 20.1$ & $10.5 / 19.4 / 19.9$ & $41.8 / 31.9 / 46.7$ \\
\hline & $(10.1 / 9.66 / 8.12)$ & $(6.79 / 8.53 / 7.88)$ & $(16.4 / 13.2 / 12.4)$ & $(17.3 / 15.2 / 13.5)$ \\
\hline
\end{tabular}


Table 4, cont'd

Estimates of Impulse Responses of $\Delta \ln (R)$ [in \%]

\begin{tabular}{|c|c|c|c|c|}
\hline \hline Shock: & ARG & BOL & BRZ & ISR \\
\hline$\varepsilon^{8}$ & $3.45 / 7.74 / 4.36$ & $9.43^{*} /-0.99 /-5.79$ & $0.70 /-0.35 /-0.04$ & $0.81^{*} / 0.76^{*} / 0.06$ \\
\hline$\varepsilon^{y}$ & $-11.2^{*} /-1.22 / 1.28$ & $-0.10 / 5.77 /-1.61$ & $-0.59 / 0.17 / 0.20$ & $-0.30 /-0.91^{*} / 0.43$ \\
\hline$\varepsilon^{\mathrm{d}}$ & $15.6^{*} /-1.38 / 1.28$ & $19.8^{*} /-13.1^{\prime \prime} /-1.68$ & $3.07^{*} /-0.30 / 0.26$ & $3.21^{*} / 0.46 / 0.21$ \\
\hline$\varepsilon^{\mu}$ & $6.19^{\prime \prime} /-3.41^{\prime \prime} /-1.84$ & $-2.60 /-7.73^{\prime \prime} / 4.96^{*}$ & $-1.10^{\prime \prime} / 0.60^{\prime \prime} /-0.23$ & $-2.82^{*} / 0.45 / 1.73^{*}$ \\
\hline
\end{tabular}

Notes: The $C_{i j}$ elements represent the long-run effect of the fiscal shock, $\varepsilon^{g}$, on government size $\left(C_{11}\right)$, ouput $\left(C_{21}\right)$, the real exchange rate $\left(\mathrm{C}_{31}\right)$, and real money balances $\left(\mathrm{C}_{41}\right)$; the long-run effect of the output shock, $\varepsilon^{y}$, on output $\left(C_{22}\right)$, the real exchange rate $\left(C_{32}\right)$, and real money balances $\left(C_{42}\right)$; the long-run effect of the preference shock, $\varepsilon^{d}$, on the real exchange rate $\left(\mathrm{C}_{33}\right)$ and real money balances $\left(\mathrm{C}_{43}\right)$; and the long-run effect of the money growth shock shock, $\varepsilon^{\mu}$, on real money balances $\left(C_{44}\right)$. In parenthesis is the coefficient's predicted sign. The reported variance decompostion (VDC) results indicate the percentage of the forecast error variance of $\Delta \ln (R)$ that is due to each shock at the 1st horizon, half-year horizon, and 4-year horizon. Standard errors obtained from Monte Carlo simulations with 1000 draws are in parenthesis. The reported impulse response results in the bottom panel indicate the response of $\Delta \ln (R)$ to a one standard deviation shock to each variable at the 1 st, half-year, and 4-year horizons. $A^{*}(\#)$ indicates significant at the 2 (1) standard error confidence level, based on t-statistics computed from 1000 random draws. 
Table 5; Results from the 4-by-4 Model with the Nominal Exchange Rate (Alternative-2)

Coefficients of the Long-Run Moving Average Matrix and

Variance Decomposition of $\Delta \ln (R)$

\begin{tabular}{|c|c|c|c|c|}
\hline Coeff: & $\mathrm{ARG}$ & $\mathrm{BOL}$ & $\mathrm{BRZ}$ & ISR \\
\hline $\mathrm{C}_{11}(+)$ & $0.90(0.81)$ & $0.37(0.19)$ & $0.70(0.36)$ & $0.57(0.14)$ \\
\hline $\mathrm{C}_{21}(+)$ & $2.40(6.24)$ & $1.10(1.73)$ & $0.01(0.25)$ & $1.27(4.38)$ \\
\hline $\mathrm{C}_{22}(-)$ & $-1.22(0.83)$ & $-0.28(0.51)$ & $-0.77(0.23)$ & $-0.47(0.35)$ \\
\hline $\mathrm{C}_{31}(-)$ & $-1.91(3.84)$ & $-1.16(1.78)$ & $0.42(2.18)$ & $-4.31(13.0)$ \\
\hline $\mathrm{C}_{32}(+)$ & $0.86(0.56)$ & $0.20(0.48)$ & $2.16(1.82)$ & $1.18(0.91)$ \\
\hline $\mathrm{C}_{33}(-)$ & $-0.56(0.13)$ & $-0.50(0.33)$ & $-0.99(0.29)$ & $-0.70(0.23)$ \\
\hline $\mathrm{C}_{41}(?)$ & $1.10(2.19)$ & $-0.71(3.25)$ & $0.89(2.05)$ & $3.01(2.73)$ \\
\hline $\mathrm{C}_{42}(-)$ & $-0.38(0.31)$ & $0.46(0.86)$ & $-0.69(2.41)$ & $-0.19(0.18)$ \\
\hline $\mathrm{C}_{43}(+)$ & $-0.12(0.22)$ & $0.25(0.21)$ & $-0.03(0.45)$ & $0.18(0.07)$ \\
\hline $\mathrm{C}_{44}(+)$ & $0.61(0.10)$ & $0.28(0.15)$ & $2.43(1.07)$ & $0.42(0.05)$ \\
\hline \multicolumn{5}{|c|}{$\mathrm{VDC} \Delta \ln (\mathrm{R})$} \\
\hline \multirow[t]{2}{*}{$\varepsilon^{\mathrm{g}}$} & $2.47 / 20.3 / 24.9$ & $29.2 / 28.3 / 23.4$ & $1.49 / 5.85 / 7.48$ & $0.14 / 3.34 / 3.39$ \\
\hline & $(13.7 / 12.7 / 11.6)$ & $(15.4 / 13.2 / 10.2)$ & $(9.51 / 7.82 / 7.65)$ & $(5.68 / 6.33 / 6.44)$ \\
\hline \multirow[t]{2}{*}{$\varepsilon^{y}$} & $90.5 / 71.8 / 61.8$ & $53.9 / 39.2 / 31.8$ & $57.2 / 47.3 / 43.6$ & $61.4 / 59.6 / 50.2$ \\
\hline & $(17.0 / 14.7 / 12.3)$ & $(21.0 / 18.1 / 13.2)$ & $(23.0 / 16.2 / 14.1)$ & $(18.2 / 15.8 / 13.6)$ \\
\hline \multirow[t]{2}{*}{$\varepsilon^{\mu}$} & $5.98 / 4.74 / 8.73$ & $1.17 / 11.6 / 29.2$ & $9.42 / 19.2 / 21.0$ & $38.4 / 36.7 / 45.6$ \\
\hline & $(8.89 / 7.12 / 9.00)$ & $(10.6 / 10.7 / 10.1)$ & $(14.4 / 12.0 / 11.2)$ & $(17.8 / 15.3 / 13.7)$ \\
\hline \multirow[t]{2}{*}{$\varepsilon^{s}$} & $1.09 / 3.14 / 4.48$ & $15.7 / 20.8 / 15.6$ & $31.9 / 27.6 / 27.9$ & $0.02 / 0.38 / 0.79$ \\
\hline & $(5.34 / 6.52 / 7.08)$ & $(14.3 / 16.6 / 10.9)$ & $(21.1 / 14.4 / 12.6)$ & $(1.73 / 2.57 / 4.13)$ \\
\hline
\end{tabular}


Table 5, cont'd

Estimates of Impulse Responses of $\Delta \ln (R)$ [in \%]

\begin{tabular}{||c|c|c|c|c||}
\hline \hline Shock: & ARG & BOL & BRZ & ISR \\
\hline$\varepsilon^{g}$ & $3.10 / 9.50^{*} / 4.58^{\prime \prime}$ & $8.11^{*} / 5.56^{\#} /-4.91^{\#}$ & $0.41 /-0.45^{\#} /-0.13$ & $-0.16 / 0.83^{\prime \prime} /-0.25$ \\
\hline$\varepsilon^{y}$ & $-18.8^{*} / 0.65 / 0.23$ & $-14.3^{\#} / 8.94^{\prime \prime} / 6.43^{\#}$ & $-2.56^{*} / 0.39 /-0.11$ & $-3.45^{*} /-0.86^{\prime \prime} /-0.14$ \\
\hline$\varepsilon^{\mu}$ & $4.83^{\prime \prime} /-0.02 /-3.90^{\prime \prime}$ & $-2.98 / 14.1^{*} /-8.19^{\#}$ & $-1.04^{\prime \prime} / 0.38 /-0.15$ & $-2.73^{*} / 0.59^{\#} / 1.77^{*}$ \\
\hline$\varepsilon^{s}$ & $2.06 /-3.34^{\prime \prime} / 2.84$ & $0.31 /-7.50^{\#} / 4.52^{\#}$ & $1.91^{*} /-0.27 /-0.07$ & $-0.06 /-0.28 / 0.26$ \\
\hline
\end{tabular}

Notes: The $\mathrm{C}_{\mathrm{ij}}$ elements represent the long-run effect of the fiscal shock, $\varepsilon^{\mathrm{g}}$, on government size $\left(\mathrm{C}_{1}\right)$, the real exchange rate $\left(C_{21}\right)$, real money balances $\left(C_{31}\right)$, and the nominal exchange rate $\left(C_{41}\right)$; the long-run effect of the output shock, $\varepsilon^{y}$, on the real exchange rate $\left(C_{22}\right)$, real money balances $\left(C_{32}\right)$, and the nominal exchange rate $\left(C_{42}\right)$; the longrun effect of the money growth shock, $\varepsilon^{\mu}$, on real money balances $\left(C_{33}\right)$ and the nominal exchange rate $\left(C_{43}\right)$; and the long-run effect of the nominal exchange rate shock, $\varepsilon^{s}$, on itself $\left(C_{44}\right)$. In parenthesis is the coefficient's predicted sign. The reported variance decompostion (VDC) results indicate the percentage of the forecast errol: variance of $\Delta \ln (R)$ that is due to each shock at the 1st horizon, half-year horizon, and 4-year horizon. Standard errors obtained from Monte Carlo simulations with 1000 draws are in parenthesis. The reported impulse response results in the bottom panel indicate the response of $\Delta \ln (R)$ to a one standard deviation shock to each variable at the: 1st, half-year, and 4-year horizons. $A^{*}(\#)$ indicates significant at the 2 (1) standard error confidence level, based on t-statistics computed from 1000 random draws. 
Chart 1; Summary of the Data

\begin{tabular}{|c|c|c|c|c|}
\hline Country/Variable & Argentina & Bolivia & Brazil & Israel \\
\hline G & $\begin{array}{l}\text { Nominal gov't } \\
\text { expenditure; } \\
\text { line } 82 \mathrm{z}^{\mathrm{a}}\end{array}$ & $\begin{array}{l}\text { Nominal gov't } \\
\text { expenditure; } \\
\text { Boliv's thous. }\end{array}$ & $\begin{array}{l}\text { Nominal gov't } \\
\text { expenditure; } \\
\text { Cruzados bill. }\end{array}$ & $\begin{array}{l}\text { Nominal gov't } \\
\text { consumption; } \\
\text { line } 91 \mathrm{f}^{\mathrm{h}}\end{array}$ \\
\hline $\mathrm{y}$ & $\begin{array}{l}\text { Real GDP; } \\
1985 \text { base; } \\
\text { line } 99 \mathrm{bp}^{\mathrm{b}}\end{array}$ & $\begin{array}{l}\text { Real GDP; } \\
1980 \text { base }^{c}\end{array}$ & $\begin{array}{l}\text { Industrial } \\
\text { production; } \\
3 / 86=100\end{array}$ & $\begin{array}{l}\text { Real GDP; } \\
1978 \text { base; } \\
\text { line } 99 \mathrm{bp}\end{array}$ \\
\hline $\mathbf{M}$ & $\begin{array}{l}\text { Nominal M1; } \\
\quad \text { line } 34\end{array}$ & $\begin{array}{l}\text { Nominal M1; } \\
\text { Boliv's hund. }\end{array}$ & $\begin{array}{l}\text { Monetary base; } \\
\text { Cruzados bill. }\end{array}$ & $\begin{array}{l}\text { Nominal M1; } \\
\text { line } 34\end{array}$ \\
\hline$P$ & $\begin{array}{c}\text { CPI, } 1985 \text { base; } \\
\text { line } 64\end{array}$ & CPI, 1980 base & $\begin{array}{c}\text { CPI, } 1985 \text { base; } \\
\text { line } 64\end{array}$ & $\begin{array}{c}\text { CPI, } 1980 \text { base; } \\
\text { line } 64\end{array}$ \\
\hline s & $\begin{array}{l}\text { Nominal exch. } \\
\text { rate, austral } / \$ \text {; } \\
\text { line rf }\end{array}$ & $\begin{array}{l}\text { Nominal exch. } \\
\text { rate, bol } \$ \$\end{array}$ & $\begin{array}{l}\text { Nominal exch. } \\
\text { rate, cruz/\$; } \\
\text { line rf }\end{array}$ & $\begin{array}{l}\text { Nominal exch. } \\
\text { rate, NIS/\$; } \\
\text { line rf }\end{array}$ \\
\hline $\mathrm{R}$ & $\begin{array}{l}\text { Ratio s times } \\
\text { U.S. CPI to P }\end{array}$ & $\begin{array}{l}\text { Ratio s times } \\
\text { U.S. CPI to P }\end{array}$ & $\begin{array}{l}\text { Ratio s times } \\
\text { U.S. CPI to P }\end{array}$ & $\begin{array}{l}\text { Ratio s times } \\
\text { U.S. CPI to P }\end{array}$ \\
\hline $\begin{array}{l}\text { Peak domestic } \\
\text { inflation rate }\end{array}$ & $\begin{array}{c}31 \% \text { in } 6 / 85 \\
190 \% \text { in } 89: \mathrm{III}\end{array}$ & $66 \%$ in $6 / 85$ & $\begin{array}{l}20 \% \text { in } 2 / 86 \\
24 \% \text { in } 6 / 87 \\
33 \% \text { in } 1 / 89 \\
59 \% \text { in } 3 / 90\end{array}$ & $52 \%$ in $85: I V$ \\
\hline Sample & 80:I - 90:IV & $80: I-90: I^{d}$ & $1 / 83-9 / 90$ & 73:IV - 91:III \\
\hline Source of data & IFS & Central bank & $\begin{array}{c}\text { IFS and central } \\
\text { bank }\end{array}$ & IFS \\
\hline
\end{tabular}

Notes: a Data is unavailable before 1980:I; ${ }^{b} \mathrm{Data}$ is unavailable after 1990:IV; ' $\mathrm{C}$ ata is unavailable before 1980:I; ${ }^{\mathrm{d} A l l}$ data is unavailable after 1990:IV; ${ }^{\mathrm{D} D a t a}$ is unavailable before $1 / 83$; ${ }^{\mathrm{f}} \mathrm{Data}$ is unavailable after $9 / 90$; ${ }^{8} \mathrm{Data}$ is unavailable before 1973:IV; 'Data is unavailable after 1991:III. A peak inflation rate quoted for a given month is a monthly rate, ancl for a quarter, is a quarterly rate. IFS denotes the IMF's International Financial Statistics; Central bank denotes the regular publications of that nation's central bank [Bulletin of the Central Bank of Bolivia (Bolivia) and Boletim Mensal do Banco Central do Brasil (Brazil)]. The series in the VAR are created as follows: (1) Gov't size, $[(\mathrm{G} / \mathrm{P}) / \mathrm{y}]=(\mathrm{g} / \mathrm{y})$; (2) Real money balances, $\ln (\mathrm{m} / \mathrm{R})\left[=\ln \left(\mathrm{M} / \mathrm{SP} \mathrm{P}^{*}\right)\right]$; (3) Real exchange rate, $\ln (\mathrm{R})$; (4) Output, $\ln (\mathrm{y})$; and (5) Nominal exchange rate change, $\operatorname{Dln}(\mathrm{s})$. 


\section{International Finance Discussion Papers}

IFDP

Number

Titles

$\underline{\text { Aughor(s) }}$

1995

501 Real Exchange Rate Movements in High Inflation Countries

John H. Rogers

Ping Wang

500 Political Competition, Casual Relations Between

Taxes and Spending, and Their Influence on

Government Size: Evidence From State-Level Data

Diane Lim Rogers

John H. Rogers

$499 \quad$ International Stock Price Spillovers and

Market Liberalization: Evidence From

Korea, Japan, and the United States

Sang W. Kim

John H. Rogers

$498 \quad$ How Wide is the Border?

Charles Engle

John H. Rogers

497 Constrained Suboptimality in Economies

David Fowman

with Limited Communication

496 Saving-Investment Associations and Capital

Mobility On the Evidence from Japanese

Regional Data

495 Convertibility Risk, Default Risk, and the

Mexdollar Anomaly

494 Government Budget Deficits and Trade Deficits:

Are Present-Value Constraints Satisfied in

Long-Term Data?

Robert Dekle

493 Real Shocks and Real Exchange Rates in Really Long-Term Data

$\underline{1994}$

492 Loss Aversion in a Consumption/Savings Model

David Flowman Deboralı Minehart Matthew Rabin

491 Terms-of-Trade Uncertainty and Economic Growth:

Enrique G. Mendoza Are Risk Indicators Significant in Growth Regressions

490 Politics, Economics, and Investment: Explaining Plant and Equipment Spending by U.S. Direct

Guy V.G. Stevens

Investors in Argentina, Brazil, and Mexico

Please address requests for copies to International Finance Discussion Papers, Division of International Finance, Stop 24, Board of Governors of the Federal Reserve System, Washington, D.C. 20551. 


\section{International Finance Discussion Papers}

IFDP

Number

489

488

487

486

484

482

481

480

479

478 On Risk, Rational Expectations, and Efficient Asset Markets

477 Finance and Growth: A Synthesis and Interpretation of the Evidence

476 Trade Barriers and Trade Flows Across Countries and Industries

475 The Constancy of Illusions or the Illusion of Constancies: Income and Price Elasticities for U.S. Imports, 1890-1992
Allan D. Brunner

Jon Faust

Ralph Tryon

Neil R. Ericsson

Michael P. Leahy

Robert Dekle

John Ammer Allan D. Brunner

Susanto Basu John G. Fernald

Graciela L. Kaminsky Michael Klein

Graciela L. Kaminsky Alfredo Pereira

R. Sean Craig

Allan D. Brunner Steven B. Kamin

Guy V.G. Stevens Dara Akbarian

Alexander Galetovic

Jong-Wha Lee Phillip Swagel

Jaime Marquez 